\title{
DOSSIÊS
}

\section{AARGENTINA ENTRE AS REFORMAS ECONÔMICAS NEOLIBERAIS E A REDEFINIÇÃO DAS NEGOCIAÇÕES COM O FMI (1989-2007) ${ }^{1}$}

\author{
Roberta Rodrigues Marques da Silva
}

\section{RESUMO}

Este artigo tem por objetivo analisar a influência da crise econômica sobre a formação de novas coalizões políticas na Argentina dos anos 2000, as quais levaram a uma ruptura em relação à política econômica adotada pelos governos Menem e De la Rúa. Essas transformações permitiram uma mudança na estratégia do governo Kirchner nas relações com o Fundo Monetário Internacional (FMI), levando a uma posição mais dura do governo argentino em rechaço às posições do Fundo. A política econômica sustentada pelos governos Duhalde e Kirchner teve como base o regime cambial competitivo, em substituição ao regime de conversibilidade vigente nos anos 1990, e contou com o apoio dos grupos empresariais voltados para o mercado doméstico, favorecidos pela desvalorização do peso. A proposta desses governos para a promoção do crescimento econômico excluiu atores com vínculos externos, que faziam parte das coalizões de apoio nas gestões Menem e De la Rúa. Entre os excluídos estavam os credores que detinham papéis da dívida em moratória desde 2001 e empresas prestadoras de serviços públicos privatizadas na década de 1990, que recebiam apoio do FMI. Essas razões explicam o fato das negociações com o Fundo durante o governo Kirchner terem sido marcadas por impasses e pela postura firme dos negociadores argentinos. Transformações no contexto internacional também tiveram impacto sobre as negociações do governo Kirchner com o FMI. Com a eleição de George W. Bush nos Estados Unidos, em 2000, enfraqueceu-se o apoio norte-americano à concessão de empréstimos do Fundo a países em desenvolvimento. O governo republicano defendeu ainda a redução do papel do FMI na intermediação das negociações entre países devedores e credores privados. O governo argentino sentia que já poderia, nessa altura, dispensar a intermediação de instituições financeiras internacionais nas negociações referentes à dívida pública.

PALAVRAS-CHAVE: Argentina; coalizões; neoliberalismo; Kirchner; FMI.

\section{INTRODUÇÃO}

Nos últimos anos, diversos países da América do Sul têm assistido à eleição de governos de esquerda e de centro-esquerda. Sua ascensão é atribuída ao fracasso do modelo neoliberal adotado nesses países durante a década de 1990, que culminou em severas crises econômico-financeiras. As crises financeiras da virada do século (Sudeste Asiático em 1997, Rússia em 1998, Brasil em 1999 e Argentina em 2001) levantaram

\footnotetext{
${ }^{1}$ Este artigo baseia-se nos resultados de minha dissertação de mestrado, apresentada ao Programa de Pós-Graduação em Relações Internacionais da Universidade Federal Fluminense (UFF) em setembro de 2008. Agradeço a Maria Antonieta Leopoldi, Victor Hugo Klagsbrunn, Vicente Palermo e Javier Vadell pelos valiosos comentários, essenciais para a elaboração deste artigo.
}

uma série de questionamentos sobre as conseqüências das reformas neoliberais, em particular da liberalização financeira. Os novos governos têm buscado implementar modelos de desenvolvimento econômico alternativos ao neoliberalismo.

A Argentina é um exemplo paradigmático desse acontecimento. O governo Carlos Menem (1989-1999), do Partido Justicialista, implantou rápidas e profundas reformas neoliberais. Também implantou um regime cambial fixo, sob o Plano de Convertibilidade, que estabelecia a paridade entre a moeda nacional (o peso) e o dólar em umpara-um. Durante toda sua vigência, o regime de conversibilidade e as reformas neoliberias foram apoiadas pelo FMI. O modelo neoliberal e o regime cambial fixo foram mantidos pelo sucessor de Menem, Fernando De la Rúa (1999-2001), da Unión Cívica Radical (UCR). 
A crise econômica havia demonstrado a vulnerabilidade do Plano de Convertibilidade e das reformas neoliberais, e acentuou o sentimento difundido entre a população de rejeição da classe política. A situação financeira do país aprofundou-se ainda mais com a retirada do apoio financeiro do Fundo Monetário Internacional (FMI). Em meio aos protestos populares, De la Rúa apresentou sua renúncia em dezembro de 2001.

A renúncia de De la Rúa permitiu a emergência de uma coalizão opositora ao governo argentino. Em 1 de janeiro de 2002, Eduardo Duhalde, rival de Menem no Partido Justicialista, assumiu provisioriamente a Presidência. Duhalde ratificou a moratória da dívida pública anunciado por seu antecessor, Adolfo Rodríguez Saá (também do Partido Justicialista), que permaneceu somente uma semana no cargo. Além disso, Duhalde anunciou o fim do Plano de Convertibilidade. Em maio de 2002, o Ministro da Economia, Roberto Lavagna, anunciou um novo regime cambial, denominado "câmbio competitivo", que estabelecia um regime de bandas cambiais, no qual a cotação do peso em relação ao dólar era mantida em torno da paridade três-para-um. Dessa forma, Lavagna pretendia estimular as exportações de bens agropecuários e a industrialização substitutiva de importações.

Em 2003, a Argentina assistiu à eleição de Néstor Kirchner, até então o desconhecido Governador da Província de Santa Cruz. Pertencente à ala mais à esquerda do Partido Justicialista, Kirchner assumiu a Presidência com intuito de dar prosseguimento ao processo de reorganização política e econômica promovido por Duhalde. Os desafios que se apresentavam ao novo Presidente eram diversos: trazer de volta a estabilização social, reorganizar o sistema político-partidário, retomar o crescimento econômico sustentado, reestruturar a dívida em moratória e normalizar as relações com o FMI, que seguiam conturbadas desde a crise de 2001.

As políticas adotadas por Kirchner - seja no plano doméstico ou externo - foram consideradas uma ruptura em relação aos governos anteriores, especialmente de Menem e De la Rúa (BONVECCHI, 2004). As negociações com o FMI, em particular, passaram a ser pautadas por estratégias diferentes. Se antes as negociações gira- vam em torno da adoção das "condicionalidades" do Fundo, com Kirchner a implementação de medidas apontadas pelo Fundo passou a levar em conta o impacto dessas medidas sobre a recuperação econômica do país, de modo a não deter o crescimento nem causar desequilíbrios sociais (VADELL, 2006).

As difíceis negociações com o FMI resultaram em um acordo firmado em 2003 que atendeu a muitas das demandas do governo argentino. As explicações para esse fato residem em acontecimentos de ordem internacional e doméstica. Transformações na ordem internacional levaram à perda da importância do FMI na concessão de pacotes de resgate financeiro e na intermediação das relações entre países soberanos e credores privados.

No âmbito doméstico, a crise econômico permitiu a emergência de uma nova coalizão governante de apoio a um novo modelo de crescimento econômico. Crises econômicas produzem controvérsias políticas que podem resultar na eleição uma nova coalizão partidária. Ao mesmo tempo, emerge um debate sobre as possíveis soluções para a crise - ou seja, entre diversas perspectivas de política econômica (policies), sejam elas tradicionais ou inovadoras. A seleção de uma dessas perspectivas em resposta à crise econômica requer o apoio da nova coalizão no poder (GOUREVITCH, 1986).

Quando surge a crise econômica, as idéias dominantes sobre a política econômica e a coalizão no poder são desafiadas, o que permite a eleição de uma nova coalizão, formada em torno de uma nova política (policy) que se julga ser necessária para restabelecer a ordem econômica. Para que se possa entender o processo de escolha de política econômica (policy), é necessário entender a política doméstica (politics), uma vez que, em última análise, as decisões sobre política econômica (policies) são tomadas por políticos, que ocupam posições institucionais que lhe garantem autoridade formal. Como os políticos almejam chegar a essas posições institucionais e nelas manterem-se, a escolha da política econômica a ser adotada é constrangida pela necessidade de reter apoio dos atores sociais (idem).

Na Argentina do governo Kirchner, a emergência de uma nova coalizão governante, apoiada sobretudo por empresários industriais voltados 
para o mercado doméstico, excluiu bancos estrangeiros, credores privados e empresas prestadoras de serviços públicos privatizados na década de 1990. Esses atores perderam o poder de veto sobre o sistema político argentino e, portanto, deixaram de exercer influência sobre as negociações com o FMI.

Este artigo propõe-se a analisar a influência de ambas as arenas sobre as negociações entre a Argentina e o FMI no governo Kirchner. Para tanto, será organizado da seguinte forma: em primeiro lugar, serão apresentadas as modificações no contexto internacional no início do século XXI. Em segundo lugar, serão apresentados os modelos de crescimento econômico levados a cabo pelos governos Menem e De la Rúa. Em terceiro lugar, será discutida a recuperação econômica ocorrida sob os governos Duhalde e Kirchner. Em seguida, serão analisadas as coalizões de governo construídas em torno da sustentação desses modelos econômicos. Posteriormente, serão discutidas as relações entre o governo argentino e o FMI entre 1989 e 2007, enfatizando-se as estratégias do governo Kirchner nas suas relações com o FMI. Por último, serão feitas algumas considerações sobre os condicionantes políticos da estratégia levada a cabo por Kirchner.

\section{A CRISE DO REGIME FINANCEIRO INTER- NACIONAL}

As crises financeiras da virada do século levaram a uma crítica ao modelo de crescimento econômico focado na captação de poupança externa, tanto no contexto doméstico dos países receptores de recursos, como no interior das próprias instituições financeiras internacionais. O momento atual caracteriza-se pela crise do regime financeiro internacional, colocando em xeque a legitimidade e a capacidade de atuação de instituições financeiras internacionais, como o Banco Mundial e o FMI (SOLA, 2008).

O FMI, em particular, perdeu espaço na intermediação das relações entre países soberanos e credores. Na década de 1980, esse organismo havia desempenhado um papel de fundamental importância nas negociações com os países em desenvolvimento, aí incluída a Argentina, para que se viabilizasse a retomada dos fluxos financeiros, interrompidos durante a crise da dívida externa. O FMI foi um dos difusores do ideário neoliberal entre os países em desenvolvimento, atrelando a concessão de empréstimos à adesão de um conjunto de reformas econômica neoliberais.

A partir da década de 1990, o crédito voltou a expandir-se na direção dos países emergentes, proveniente de múltiplos credores privados, proporcionando a incorporação e consolidação do modelo de crescimento econômico associado à captação de poupança externa (BRESSER-PEREIRA \& NAKANO, 2003). O FMI tornou-se, nesse período, uma referência entre os países latinoamericanos. $\mathrm{O}$ aval do organismo foi essencial para a captação de recursos.

Na década de 1990, alguns procedimentos associados à aprovação de empréstimos aos países em desenvolvimento (“condicionalidades”), ligados às receitas neoliberais do FMI, foram suavizados na concessão de financiamentos deste banco a países latino-americanos, como a Argentina. A preocupação com a austeridade fiscal e o apoio ao regime de câmbio fixo não mais tiveram o caráter de exigência do passado. Essas mudanças fizeram-se necessárias justamente para que o país pudesse enfatizar o programa de reformas orientadas para o mercado, ao mesmo tempo em que promoviam a estabilidade dos preços via apreciação cambial. O relaxamento das metas fiscais, por sua vez, associava-se à crença de que a captação de poupança externa promoveria o crescimento econômico a longo prazo, sanando os problemas de curto prazo relativos aos deficits fiscais.

A promoção do crescimento econômico por meio de reformas para o mercado, que representava um objetivo das instituições financeiras internacionais, contudo, não se concretizou. O crescimento registrado durante toda a década de 1990 nos países sul-americanos foi medíocre, e culminou em severas crises financeiras que levaram a desvalorizações cambiais e, particularmente no caso argentino, à moratória da dívida.

O FMI sofreu a partir de então severas críticas, tanto internas quanto externas: os novos governos dos países sul-americanos passaram a descartar os recursos do Fundo, buscando investimentos alternativos para promover seu crescimento econômico e reduzir a carga da dívida e/ou dos juros em relação ao Produto Interno Bruto (PIB), favorecidos pelo bom momento da economia internacional, que se estendeu até 2008. Muitos governantes desses países responsabilizaram o 
próprio FMI pelas crises financeiras, alegando que o Fundo recomendara políticas equivocadas, que teriam desembocado nessas crises.

O FMI atravessou uma crise interna, gerada por uma mudança na orientação do governo norte-americano, seu principal provedor de recursos, em suas relações com o organismo ${ }^{2}$. A partir do governo republicano de George W. Bush (2000-2008), enfraqueceu-se o apoio norte-americano à concessão de empréstimos a países em desenvolvimento, além de ter predominado na instituição uma visão mais liberal no que diz respeito às relações entre países devedores e credores privados.

Os atentados terroristas de 11 de setembro de 2001 também consistiram em um ponto de inflexão da política externa norte-americana. Após os ataques aos prédios do Pentágono e do World Trade Center, o governo Bush privilegiou ações ligadas à chamada "guerra contra o terror", o que acabou por ampliar os espaços de manobra de países em desenvolvimento não diretamente envolvidos nessa questão, como a Argentina (VADELL, 2006).

Embora a crise do regime financeiro internacional ${ }^{3}$ voltado para a liberalização não tenha levado ao seu fim, ainda não se vislumbram saídas para o impasse. Vários fatores somam-se hoje na pintura de um cenário pouco favorável à reabilitação desse sistema, sob liderança norte-americana, em favor da implantação de políticas liberalizantes: (1) a crise financeira norte-americana; (2) o crescimento de países em desenvolvimento que não se alinharam ao neoliberalismo, como China e Índia, que levaram à alta dos pre-

\footnotetext{
2 Os Estados Unidos são o ator com poder de veto no processo decisório do FMI, concentrando 17,45\% das cotas do organismo.

3 Segundo Krasner, um regime internacional é um “conjunto de princípios, normas, regras e procedimentos de tomada de decisão implícitos e explícitos em torno do qual as expectativas dos atores convergem em uma dada área temática. Princípios são crenças de fato, causa e retificação. Normas são padrões de comportamento definidos em termos de direitos e obrigações. Regras são prescrições específicas para a ação. Procedimentos de tomada de decisão são "práticas prevalecentes para se fazer e implementar a escolha coletiva.” (KRASNER, 1983, p. 3; tradução nossa)
}

ços das commodities no mercado internacional e sustentaram o crescimento de diversos países em desenvolvimento; (3) as difíceis negociações no âmbito da Rodada de Doha da Organização Mundial do Comércio (OMC), resultantes das posições de países desenvolvidos, como os Estados Unidos, contrapondo-se a importantes economias emergentes, como China e Índia, apontam para um cenário de fortalecimento do protecionismo comercial.

Esses fatores, ainda que não determinem os resultados de negociações internacionais entre países em desenvolvimento e instituições financeiras internacionais ou países desenvolvidos, certamente expõem a crise normativa pela qual passa, já há alguns anos, o regime financeiro (liberal) internacional, conferindo aos países em desenvolvimento maior margem de manobra no meio internacional.

II. AARGENTINADAS REFORMAS MENEMISTAS À CRISE (1989-2001): PLANO DE CONVERTIBILIDADE, REFORMAS NEOLIBERAIS E COLAPSO FINANCEIRO

Desde sua eleição, em 1989, Menem pautou sua política econômica pela busca por estabilizar a economia, combater a inflação e equilibrar as contas públicas. Para tanto, promoveu reformas neoliberais, que giraram em torno de três eixos: privatizações, abertura comercial e liberalização financeira (RAPOPORT, 2000).

Para combater a inflação, o Ministro da Economia Domingo Cavallo anunciou o Plano de Convertibilidade em 1991. Esse plano constituía o regime de currency board, no qual a taxa de câmbio foi fixada na livre conversão de um peso por dólar. O regime cambial adotado resultou em uma brusca alteração dos preços relativos, redundando em perdas para os exportadores e em maior demanda por bens importados (RAPOPORT, 2000; MUSSA, 2002). A Argentina passou a experimentar deficits crônicos na balança comercial, que seriam compensados pela entrada de fluxos substanciais (e crescentes) de fluxos de capitais externos (FRENKEL \& RAPETTI, 2006).

A política econômica adotada logo mostrouse bem sucedida na estabilização dos preços. Além disso, a atividade econômica expandiu-se continuamente até a crise mexicana em 1995 (RAPOPORT, 2000). 
TABELA 1-ARGENTINA: CRESCIMENTO DO PIB E INFLAÇÃO - 1990-2001

\begin{tabular}{|lcc|}
\hline Ano & Crescimento do PIB (\%) & Inflaçäo (\%) \\
\hline 1990 & $-1,83$ & $2.313,96$ \\
1991 & 10,58 & 171,68 \\
1992 & 9,61 & 24,90 \\
1993 & 5,72 & 10,54 \\
1994 & 5,84 & 4,29 \\
1995 & $-2,85$ & 3,40 \\
1996 & 5,53 & 0,16 \\
1997 & 8,11 & 0,53 \\
1998 & 3,85 & 0,92 \\
1999 & $-3,39$ & $-1,17$ \\
2000 & $-0,79$ & $-0,94$ \\
2001 & $-4,41$ & $-1,07$ \\
\hline
\end{tabular}

Nesse período, o ambiente externo também mostrava-se favorável ao bom desempenho da economia argentina: o crédito voltou a expandir-se na direção dos países emergentes, no marco do Plano Brady ${ }^{4}$. Esse fluxo financeiro significou, de fato, o motor do crescimento de diversas economias do continente, associado à captação de poupança externa (BRESSER-PEREIRA \& NAKANO, 2003).

Inicialmente, o FMI manifestou sua preocupação com a vulnerabilidade a choques externos a que se submetia a economia argentina sob o regime de currency board. O primeiro teste de resistência desse mecanismo ocorreu durante a crise no México, em 1994, que levou à desvalorização da moeda mexicana. Diversos analistas acreditavam que a Argentina, economia emergente com características semelhantes ao México ${ }^{5}$, seria o próximo país a desvalorizar sua moeda em decorrência dos ataques especulativos e da fuga de capitais. De fato, a economia argentina apresentou uma retração naquele ano, mas essa tendência acabou por reverter-se. O FMI apoiou a manutenção do regime de conversibilidade por meio de um acordo que revisava as metas fiscais, permitindo uma relação maior entre gastos públicos e o PIB. Em 1995, foi retomado o crescimento econômico da Argentina (MUSSA, 2002).

TABELA 2 - ARGENTINA: INDICADORES SOBRE A DÍVIDA - 1990-2001

\begin{tabular}{|c|c|c|c|c|}
\hline Ano & $\begin{array}{l}\text { Dívida externa total } \\
\text { (milhóes de dólares) }\end{array}$ & $\begin{array}{c}\text { Dívida externa total / } \\
\text { PIB (\%) }\end{array}$ & $\begin{array}{c}\text { Dívida do govemo } \\
\text { central / PIB (听) }\end{array}$ & $\begin{array}{c}\text { Serviço da divida i } \\
\text { exportaçóes (听) }\end{array}$ \\
\hline 1990 & 60.674 & 46,75 & n.d. & 52,88 \\
\hline 1991 & 64.551 & 37,06 & n.d. & 49,86 \\
\hline 1992 & 71.217 & 33,87 & n.d. & 33,22 \\
\hline 1993 & 75.680 & 31,97 & 29,44 & 34,07 \\
\hline 1994 & 89.927 & 34,90 & 31,20 & 36,49 \\
\hline 1995 & 101.885 & 39,48 & 33,75 & 35,10 \\
\hline 1996 & 111.623 & 41,00 & 35,68 & 48,06 \\
\hline 1997 & 125.039 & 42,67 & 34,52 & 47,89 \\
\hline 1998 & 140.173 & 47,05 & 37,58 & 57,05 \\
\hline 1999 & 145.430 & 51,27 & 42,99 & 76,02 \\
\hline 2000 & 146.475 & 51,51 & 45,04 & 77,27 \\
\hline 2001 & 140.530 & 52,27 & 53,76 & 99,82 \\
\hline
\end{tabular}

Fonte: Faucher e Armijo (2003).

\footnotetext{
4 O Plano Brady - assim conhecido em referência ao Secretário do Tesouro dos Estados Unidos Nicholas Brady , permitia a reestruturação da dívida "mediante a troca por bônus de emissão do governo do país devedor, que [contemplavam] abatimento do encargo da dívida, seja sob a forma de redução do seu principal, seja por alívio na carga de juros." (BRASIL, 2007, p. 42).
}

5 A economia do México, assim como a da Argentina, caracterizava-se pela sobrevalorização real da moeda, pelos desequilíbrios em conta corrente e pelo progressivo aumento da dívida. 
A crise mexicana também revelou a fragilidade do sistema bancário dos países emergentes quando expostos aos efeitos adversos de uma crise cambial. Por isso, o governo argentino promoveu uma reforma no sistema bancário, em meados de 1994, privatizando bancos estatais e encorajando os bancos comerciais a manter linhas de crédito em moeda estrangeira, para o caso de uma eventual crise cambial. Os bancos passaram, portanto, a realizar negócios em dólares e pesos sob a garantia de livre conversão dada pelo governo (idem).

A popularidade do Plano de Convertibilidade manteve-se elevada durante todo o governo Menem. Com a eleição de De la Rúa (UCR), em 1999, a defesa do regime cambial vigente seguiu como política econômica principal (main policy) da agenda pública. Durante a campanha, De la Rúa prometeu manter o Plano de Convertibildiade, mas corrigir alguns do resultados negativos associados ao modelo neoliberal, como o aumento do desemprego, pobreza e indigência (WISE, 2001).

De la Rúa chegou à Presidência em um contexto de recessão econômica. A defesa do Plano de Convertibilidade levou-o a optar por seguir uma política fiscal contracionista, a fim de evitar que o país interrompesse os pagamentos junto aos credores. Dentre as medidas tomadas, incluíram-se aumento de impostos e a cortes nos gastos público. Um novo acordo firmado com o FMI em 2000 - conhecido como "blindagem financeira" - permitiu a contração de recursos para honrar os pagamentos da dívida pública previstos para 2001 (RAPETTI, 2005).

Contudo, o desempenho da economia também manteve-se aquém do esperado, levando o governo a enfrentar dificuldades para cumprir as metas fiscais programadas com o FMI para 1999 e 2000. A fim de manter a confiança do investidor, De la Rúa recorreu novamente ao FMI. Para evitar resultados catastróficos - crise financeira, moratória e fim do Plano de Convertibilidade - o Fundo manteve a ajuda financeira, dessa vez muito superior àquelas convencionalmente concedidas. Em contrapartida, o governo deveria adotar medidas consistentes com a consolidação fiscal (MUSSA, 2002).

No começo de 2001, De la Rúa convidou Cavallo, autor do Plano de Convertibilidade, para ocupar o Ministério da Economia. Cavallo conseguiu a aprovação, pelo Congresso, de "poderes vastos (mas não ilimitados) para o Presidente adotar medidas econômicas por decreto", o que resultou no aumento de impostos, na criação de um imposto sobre transações financeiras ${ }^{6}$ e na adoção de medidas que pretendiam promover o crescimento e atrair investimentos (idem, p. 25. Tradução da autora). Também conseguiu no Congresso a aprovação da Lei de "Deficit Zero", que determinava o equilíbrio imediato das contas nacionais. Dessa forma, pretendia garantir o pagamento dos juros da dívida e as transferências às províncias (DAMILL, FRENKEL \& RAPETTI, 2005).

A situação, contudo, não tardou a deteriorar: os juros subiram, a recessão acentuou-se e a relação dívida/PIB elevou-se, redundando em corridas aos bancos e novas perdas de reservas. Em meados de novembro, Cavallo anunciou que iria a Washington em busca de novas negociações com o FMI, mas o Diretor Gerente do organismo, Horst Köhler, declarou que ele não seria recebido (MUSSA, 2002). No mês seguinte, o FMI anunciou que não seriam liberados novos empréstimos à Argentina.

A retirada do apoio do FMI deixou o país sem acesso a recursos em moeda estrangeira. Como a corrida aos bancos prosseguia, o governo anunciou o fechamento dos bancos. Quando reabertos, os saques foram temporariamente restritos a US\$ 250 por semana, medida que fcou conhecida como corralito (idem).

O clima de insatisfação popular, que já havia levado a diversas manifestações ao longo dos meses anteriores, ganhou força com o anúncio do corralito. Recessão econômica, cortes de gastos públicos - inclusive na área social -, redução dos salários dos servidores públicos, desemprego em torno de $20 \%$, pobreza e a indigência sem precedentes, tudo contribuiu para que a população tomasse as ruas em manifestações contra o governo. Com panelas nas mãos, a população argentina, sem distinção de classes sociais, organizou manifestações, conhecidas como "panelaços", que atravessaram as noites. $\mathrm{O}$ anúncio do corralito representou não só uma dificuldade financeira a mais para as famílias argentinas, como colocou em destaque a prioridade da agenda pública do governo De la

\footnotetext{
6 Esse imposto é semelhante à Contribuição Provisória sobre Movimentação Financeira (CPMF) adotada pelo Brasil.
} 
Rúa: o pagamento dos juros da dívida pública e a manutenção do Plano de Convertibilidade. As precoupações sociais estiveram sempre em segundo plano. De la Rúa não resisitu à pressão popular e apresentou sua renúncia.

AAssembléia Legislativa teve que se reunir para indicar um novo Presidente. Dentre os nomes que ocuparam a Presidência da República esteve Adolfo Rodríguez Saá (PJ), Governador de San Luís. Rodríguez Saá declarou a moratória da dívida pública, sem consultar previamente os credores ou detentores de títulos argentinos. Sua passagem pela Presidência durou menos de uma semana: ele acabou por ser derrubado e substituído por Duhalde. O novo Presidente declarou o fim - inevitável - do Plano de Convertibilidade, nos primeiros dias de 2002 (TORRE, 2004).

\section{A ECONOMIA ARGENTINA DA CRISE À RECUPERAÇÃO: OS GOVERNOS DUHALDE E KIRCHNER}

Ao assumir interinamente a Presidência da República para cumprir o resto do mandato de De la Rúa, Duhalde tinha como objetivos estabilizar o país tanto na esfera econômica quanto política. Apesar do ambiente de incerteza e desconfiança a respeito dos rumos da economia argentina - muitos analistas, inclusive no FMI, esperavam que o país experimentasse uma profunda recessão -, houve uma rápida recuperação, iniciada apenas um trimestre após a ocorrência dos eventos que levaram ao colapso do Plano de Convertibilidade.

O fim do regime de conversibilidade, embora tenha elevado automaticamente o montante do endividamento - 97\% da dívida pública estava denominada em dólares -, reduziu a vulnerabilidade externa. Significou ainda a quebra dos contratos com empresas que prestavam serviços públicos privatizados, uma vez que o governo determinou que as tarifas deveriam ter seus preços em pesos, contrariando os contratos que os vinculavam ao dólar. Dessa forma, evitou-se a subida brusca dos preços das tarifas desses serviços.

Depósitos bancários denominados em dólares - cerca de $64 \%$ do total - também foram compulsoriamente convertidos em pesos a uma taxa de 1,4 peso por dólar. Os créditos bancários mantiveram a cotação de um peso por dólar (DAMILL, FRENKEL \& RAPETTI, 2005, p. 34).

Esse tipo de câmbio "dual” encontrou resistência no FMI, cujos representantes afirmaram que não haveria negociações no caso de manutenção dessa medida. Pressionado, o governo adotou a livre flutuação do peso. Com a disparada do câmbio, que levou o dólar à cotação de quase quatro pesos (em parte devido às especulações), foram introduzidos controles cambiais (idem; RAPETTI, 2005; FRENKEL \& RAPETTI, 2006).

Com a posse de Roberto Lavagna no Ministéro da Economia, em maio de 2002, foi lançada a política de "câmbio competittivo", que estabelecia a intervenção do Banco Central no mercado de câmbio, a fim de manter a competitividade das exportações. Quando introduzida, essa medida manteve a cotação do dólar entre 2,8 a 3 pesos. Essa política permitiu o aumento das exportações de bens agro-pecuários e a da industrialização substitutiva de importações (FRENKEL \& RAPETTI, 2006).

O governo Duhalde criou ainda uma tributação sobre as exportações, conhecida como "retenções”, com o objetivo de transferir para o Fisco parte dos lucros obtidos com o aumento das exportações, proporcionado pelo regime cambial competitivo e pela elevação dos preços das commodities no mercado internacional (DAMILL, FRENKEL \& RAPETTI, 2005, p. 28).

Após a introdução do novo modelo cambial, registraram-se elevados índices de crescimento econômico, acompanhados de superavits externos e fiscais. A austeridade fiscal deveu-se aos cortes de gastos, ao aumento da arrecadação favorecida pelo crescimento econômico, às tributações sobre as exportações e à suspensão do pagamento de juros em virtude da moratória (FRENKEL \& RAPETTI, 2006).

TABELA3 -ARGENTINA: CRESCIMENTO DO PIB E INFLAÇÃO - 2002-2007

\begin{tabular}{|ccc|}
\hline & Crescimento do PIB & Inflação (舞) \\
\hline 2002 & $-10,9$ & 25,9 \\
2003 & 8,8 & 13,4 \\
2004 & 9,0 & 4,4 \\
2005 & 9,2 & 9,6 \\
2006 & 8,6 & 10,9 \\
$2007^{1}$ & 8,7 & 8,5 \\
\hline
\end{tabular}

Fonte: Organización de las Naciones Unidas (2008); Argentina (2008a).

Nota: De acordo com especialistas, a inflação de 2007 girou, na realidade, entre 15 e $20 \%$ (CRISTINA'S CHALLANGES, 2007). 
Kirchner, eleito em maio de 2003, deu continuidade ao modelo de crescimento econômico baseado no câmbio competitivo. Inicialmente, ele manteve Lavagna no Ministério da Economia. Em conseqüência da desvalorização cambial, tornouse possível a reativação de plantas industriais que haviam sido fechadas durante a década de 1990, em função da concorrência dos produtos importados. Não foram introduzidas, contudo, outras medidas "ativas" para a promoção da industrialização (COSTA, KICILLOF \& NAHÓN, 2004, p. 14-15).
Kirchner traçou ainda como objetivos a austeridade fiscal e a política de rendas, que incluía a mediação do Estado no conflito distributivo a fim de limitar seus efeitos sobre as expectativas inflacionárias. Essa política abrangia medidas relativas à previdência social, às negociações coletivas de salários, à política de preços (subsídios aos produtores de bens que compõem a cesta básica e acordos de preços com o setor privado) e à tributação sobre as exportações (ARGENTINA, 2007).

TABELA 4 - ARGENTINA: AJUSTE FISCAL: RESULTADO DO SETOR PÚBLICO CONSOLIDADO (EM PORCENTAGEM DO PIB)

\begin{tabular}{|llccc|}
\hline Nível de Governo & Indicadores & \multicolumn{3}{c|}{ Ano } \\
\hline & & $\mathbf{1 9 9 8}$ & $\mathbf{2 0 0 1}$ & $\mathbf{2 0 0 4}$ \\
\hline Governo Nacional & Ingressos totais & 18,9 & 18,8 & 23,5 \\
& Ingressos tributários & 13,5 & 13,8 & 18,7 \\
& Tributaçẫo sobre exportaçỗes & 0,0 & 0,0 & 2,3 \\
& Gastos totais & 20,3 & 22,0 & 20,9 \\
& Gasto primário & 18,0 & 18,2 & 19,6 \\
& Juros & 2,2 & 3,8 & 1,3 \\
& Resultado primário & 0,9 & 0,5 & 3,9 \\
Províncias & Resultado primário & $-0,3$ & $-1,5$ & 1,4 \\
Setor Público Consolidado & Resultado primário consolidado & 0,6 & $-0,9$ & 5,2 \\
\hline
\end{tabular}

Fonte: Rapetti (2005).

TABELA 5 - ARGENTINA: INDICADORES SOBRE A DÍVIDA - 2002-2007

\begin{tabular}{|c|c|c|c|c|c|}
\hline Ano & $\begin{array}{c}\text { Dívida } \\
\text { Externa Bruta } \\
\text { Total (bilhões } \\
\text { de dólares) }\end{array}$ & $\begin{array}{c}\text { Dívida do } \\
\text { Gowerno } \\
\text { Nacional / PIB } \\
\text { (呴) }\end{array}$ & $\begin{array}{c}\text { Dívida do } \\
\text { Governo Nacional } \\
\text { Interna / PIB } \\
\text { (听) }\end{array}$ & $\begin{array}{c}\text { Dívida do Gover- } \\
\text { no Nacional } \\
\text { Externa / PIB } \\
\text { (D) }\end{array}$ & $\begin{array}{l}\text { Pagamento de } \\
\text { Juros da } \\
\text { Dŕvida / PIB } \\
\text { (㣙) }\end{array}$ \\
\hline 2002 & 157 & 145,9 & 52,8 & 93,0 & 2,1 \\
\hline 2003 & 165 & 138,2 & 59,4 & 78,8 & 1,9 \\
\hline 2004 & 171 & 126,4 & 52,7 & 73,8 & 1,3 \\
\hline 2005 & 114 & 72,8 & 38,3 & 34,5 & 1,9 \\
\hline
\end{tabular}

Fonte: Organización de las Naciones Unidas (2007).

Segundo o pessoal do FMI, o governo deveria lançar mão da elevação dos juros para conter a inflação. O governo argentino, entretanto, não acatou essas recomendações, defendendo que a política cambial adotada, associada à manutenção de uma taxa de juros historicamente baixa, era essencial para a promoção do crescimento econômico e a redução do desemprego. O governo contava com um "pacto social” para controlar a inflação, baseado no apoio de industriais e sindicatos. Também foi importante para conter a inflação a manutenção do congelamento das tarifas dos serviços públicos privatizados (DAMILL, FRENKEL \& RAPETTI, 2005, p. 29). Não obstante as medidas adotadas, as pressões inflacionárias mantiveram-se presentes. Ao fim de sua gestão, Kirchner foi acusado de manipular os índices oficiais de inflação que, segundo estimativas não oficiais, giravam em torno de $20 \%$. 
Kirchner teve de lidar ainda com questões relativas à renegociação da dívida em moratória. $\mathrm{O}$ governo considerava essencial a reestruturação da dívida argentina em moratória desde 2001 para a sustentabilidade do crescimento econômico, viabilizada pela atração de financiamento a médio e longo prazos (COSTA, KICILLOF \& NAHÓN, 2004; MENDONÇA, 2005).

A proposta a ser apresentada, porém, não deveria entrar em conflito com as metas de crescimento econômico e redução da pobreza (COSTA, KICILLOF \& NAHÓN, 2004, p. 2). O Presidente afirmou em seu discurso de posse que não normalizaria os pagamentos da dívida "em troca da fome e da exclusão dos argentinos" (THE EMPTY-HANDED SOCIAL DEMOCRAT. ARGENTINA'S NEW PRESIDENT, 2003; tradução da autora).
Depois de difíceis negociações, o governo apresentou, em junho de 2004, uma proposta na qual se estabelecia o desconto de $75 \%$ sobre o valor nominal da dívida 7 . A proposta apresentada pelo governo Kirchner era inédita: nunca antes um país havia pedido a redução do valor de face dos títulos, o corte dos juros e a extensão de seu prazo de resgate (MORTIMORE \& STANLEY, 2006).

Em 12 de janeiro de 2005, deu-se o começo da troca de 152 títulos antigos por três novos, encerrado em 25 de fevereiro de 2005. O governo recebeu $76,15 \%$. O estoque da dívida pública foi reduzido em cerca de quase $150 \%$ para $80 \%$ do PIB. O perfil da dívida também mudou após a operação: 44\% do total de títulos emitidos passaram a vincular-se à moeda local, a um prazo de vencimento maior (DAMILL, FRENKEL \& RAPETTI, 2005, p. 45; MENDONÇA, 2005).

TABELA 6 - ARGENTINA: PROCESSO DE REESTRUTURAÇÃO DA DÍVIDA: VALORES OFERECIDOS E TROCADOS (EM BILHÕES DE DÓLARES)

\begin{tabular}{|c|c|c|c|c|}
\hline $\begin{array}{l}\text { Títulos } \\
\text { novos }\end{array}$ & $\begin{array}{l}\text { Desconto por } \\
\text { título } \\
\text { (听) }\end{array}$ & $\begin{array}{l}\text { Dívida nova oferecida } \\
\text { pelo governo argentino } \\
\text { para troca }\end{array}$ & $\begin{array}{l}\text { Nowos títulos } \\
\text { trocados }\end{array}$ & $\begin{array}{l}\text { Adesão por } \\
\text { título }\end{array}$ \\
\hline Par & 0 & 15,0 & 15,0 & 100 \\
\hline Cuasi-Par & 31,1 & 8,3 & 8,3 & 100 \\
\hline Disc ount & 66,3 & 18,5 & 11,9 & 64,3 \\
\hline Total & & 41,8 & 35,2 & 76,15 \\
\hline
\end{tabular}

Fonte: Mendonça (2005).

O pessoal do FMI, apesar de contrário à proposta apresentada e à postergação do acordo com os credores que não aderiram ao acordo, foi pressionado pelo governo dos Estados Unidos (sob a gestão republicana de Bush) a não interferir nos assuntos relativos à renegociação da dívida. De acordo com a posição norte-americana, parte da culpa pela crise argentina recaía sobre os credores, cuja conduta teria sido influenciada pelas atitudes passadas do FMI como "prestamista de última instância” (idem; idem).

As instituições financeiras internacionais desempenharam um papel praticamente nulo durante o processo de reestruturação da dívida argentina. Alguns dos governos de países membros do G-7 mostraram-se refratários à postura de laissezfaire do governo Bush, mas viram seu poder de pressão reduzido devido à baixa coesão no interior do grupo (MORTIMORE \& STANLEY, 2006).
IV. A POLÍTICA DAS REFORMAS NA ERA MENEM (1989-1999): INSTITUIÇÕES, COALIZÕES E POLÍTICAS GOVERNAMENTAIS

Menem (PJ) chegou à Presidência da Argentina em 1989, eleito em primeiro turno, recebendo 47,49\% dos votos válidos (ARGENTINA, 2008b). Sua plataforma eleitoral prometia o "salariazo" e a "revolução produtiva”, prometendo combater a hiperinflação e promover o crescimento econômico.

Contrariando as expectativas iniciais, logo que chegou ao poder, Menem buscou o apoio dos principais grupos econômicos - credores externos e

7 O deságio sobre o valor de face dos títulos da dívida argentina refletiam, de certo modo, a própria leitura do mercado, que já cotava os bônus argentinos a cerca de $30 \%$ de seu valor original (COSTA et al., 2004; MENDONÇA, 2004) 
conglomerados estrangeiros e locais. Adotou uma agenda econômica orientada para o mercado, promovendo desde o início de sua gestão privatizações, abertura comercial e liberalização financeira (SCHVARZER, 1994; RAPOPORT, 2000).

Para promover as reformas neoliberais, o Congresso delegou poderes legislativos ao Presidente por meio da Lei de Reforma do Estado e da Lei de Emergência Econômica (1989). Embora tenha contado com maioria no Parlamento durante quase todo o mandato, Menem concentrou poder em épocas de crise e de estabilidade, governando de forma unilateral. O Presidente abusou do recurso aos decretos de necessidade e urgência (DNUs) (DE LUCA, 2007).

O alinhamento em torno da liderança de Menem não foi automático. As reformas econômicas adotadas não avançaram em todos os setores com destaque para as áreas trabalhista e previdenciário - justamente em razão da necessidade de construção de uma coalizão de apoio ao governo Menem. Permitiu-se a permanência de "enclaves não liberais" no setor trabalhista e a manutenção do regime de transferência de recursos para as províncias (conhecido como co-participação ${ }^{8}$ ) sem que houvesse, em contrapartida, comprometimento com a austeridade fiscal no nível subnacional (BAER, GALLO \& ELOSEGUI, 2001; WISE, 2001).

Particularmente durante seu primeiro mandato, Menem recebeu o apoio de uma coalizão que incluía setores empresariais orientados para o mercado externo, uma parte significativa do sindicalismo (que mantinha vínculos estreitos com o peronismo) e os consumidores, reunidos ao redor da promessa de estabilização dos preços (STARR, 1997).

A seguir, reproduzimos o quadro elaborado por Baer, Gallo e Elosegui (2001) em que se registra a relação de beneficiados e não-beneficiados pelo projeto reformista de orientação para o mercado durante o primeiro mandato de Menem:

\section{QUADRO 1 -ARGENTINA: BENEFICIADOS E NÃO-BENEFICIADOS PELAS REFORMAS NEOLIBERAIS}

\begin{tabular}{|c|c|c|}
\hline Beneficiados & Não-beneficiados & Sem mudança \\
\hline $\begin{array}{l}\text { Irwestidores externos e } \\
\text { grupos corporativos locais } \\
\text { (privatizaçốes). }\end{array}$ & $\begin{array}{c}\text { Servidores públicos } \\
\text { (privatizaçốes) e sindicatos. }\end{array}$ & $\begin{array}{l}\text { Províncias: sofreram algum ajuste, mas } \\
\text { evitaram alguns outros. Durante esse } \\
\text { período o ajuste estatal c oncentrouse } \\
\text { principalmente no governo federal. }\end{array}$ \\
\hline $\begin{array}{l}\text { Classes médias e baixas } \\
\text { (boom c onsumista, } \\
\text { aumento na renda real, } \\
\text { crédito, inflaçẫo baixa). }\end{array}$ & $\begin{array}{l}\text { Setor exportador } \\
\text { (sobrevalorizaçẫo cambial, } \\
\text { reduçẫo do protecionismo). }\end{array}$ & \\
\hline $\begin{array}{l}\text { Setor bancário e de } \\
\text { serviços. }\end{array}$ & $\begin{array}{l}\text { Setor industrial (mais } \\
\text { competiçấo, menos } \\
\text { privilégios). }\end{array}$ & \\
\hline
\end{tabular}

Fonte: Baer, Gallo e Elosegui (2001).

Em 1994, Menem passou a concentrar esforços na aprovação da Reforma Constitucional, que lhe garantiu a possibilidade de candidatar-se à reeleição. Ele acabou por reeleger-se, apresentando-se como único candidato capaz de manter afastado o "fantasma" da crise econômica e da hiperinflação, em uma conjuntura de crise gerada pelo contágio da crise mexicana (NOVARO, 2006). Menem obteve uma expressiva vitória nas urnas, sendo eleito no primeiro turno com 49,94\% dos votos válidos (ARGENTINA, 2008b).

Não obstante a reeleição no primeiro turno, surgiram conflitos internos no governo (notadamente entre o Ministro Cavallo e o Presidente) que acentuaram o descontentamento popular, tanto em relação aos sucessivos escândalos de corrupção quanto aos efeitos negativos das reformas de orientação para o mercado, particularmente o aumento do desemprego e o recuo da renda (NOVARO, 2006).

\footnotetext{
8 A legislação sobre a coparticipação estabelecia um regime de transferências de recursos do governo central para as províncias, uma vez que o primeiro arrecada um montante expressivamente superior de tributos em comparação às últimas.
} 
Durante seu segundo mandato, a agenda reformista não registrou muitos avanços: as chamadas "reformas de segunda geração", que garantiriam maior transparência e concorrência, contrariavam os interesses dos empresários ligados a monopólios e oligopólios formados durante as privatizações. Além disso, a reforma trabalhista encontrou resistência por parte dos setores sindicais, que haviam mantido-se em silêncio ao longo do processo reformista ocorrido no primeiro mandato (NOVARO, 2006).

Os bancos estrangeiros ganharam maior centralidade na coalizão menemista durante o seu segundo mandato, após a crise de 1994-1995. Durante a crise, o governo promoveu um processo de reestruturação do sistema bancário que garantiu sua melhor adaptação às novas condições de inserção financeira do país no mercado internacional, mas resultou no fechamento dos bancos menores. A partir de então, o sistema bancário argentino passou a contar, majoritariamente, com bancos de origem estrangeira.

Com o afastamento do receio de retorno da inflação, o setor industrial passou a apresentar queixas contra a concorrência desleal dos produtos importados, favorecidos pelo regime de conversibilidade. Entretanto, a desestruturação do tecido industrial argentino ao longo da década de 1990 enfraqueceu o poder do setor na barganha política. Esse processo também enfraqueceu o sindicalismo que, dividido entre três grandes organizações, não foi capaz de coordenar suas ações. Pelo contrário, dentro do movimento sindical encontravam-se grupos que ofereciam apoio irrestrito ao governo Menem (como a CGT Confederación General del Trabajo), em razão de suas vinculações com o peronismo ${ }^{9}$. A CGT só reviu sua estratégia durante o segundo mandato de Menem, em decorrência da deterioração das condições econômicas, particularmente do aumento do desemprego (STARR, 1997).

Os governos provinciais também são atoreschave para a compreensão do modelo menemista: a manutenção de déficits fiscais pode ser explicada, em larga medida, pelo desequilíbrio das

9 Os sindicatos aliados ao governo haviam apoiado as privatizações como moeda de troca para a posterior colaboração com o governo nas negociações sobre a reforma trabalhista (ARMIJO \& FAUCHER, 2002). contas provinciais. Os governos provinciais beneficiaram-se, ao longo da década de 1990, das transferências de recursos realizadas pelo governo federal, garantidas pelos fundos de co-participação. Esse regime dificilmente poderia ser modificado em um contexto político como o argentino, no qual os Governadores provinciais possuem forte capital político (BONVECCHI, 2005).

Ao final de seu segundo mandato, Menem lançou uma campanha para que fosse realizada uma nova modificação na Constituição, que lhe garantisse a possibilidade de candidatura ao terceiro mandato consecutivo. Em vista das resistências no interior do próprio partido - dividido desde as eleições legislativas de 1997, em que o peronismo foi derrotado -, o Presidente teve que desistir desse projeto político (NOVARO, 2006).

O enfraquecimento do peronismo contribuiu para elevar o descontentamento popular em relação aos efeitos negativos das reformas neoliberais - aumento da pobreza, da concentração de renda e do desemprego - e às práticas de corrupção difundidas no governo. A UCR e a Frepaso ${ }^{10}$, os dois maiores partidos de oposição ao peronismo na década de 1990, uniram-se na coalizão partidária denominada Alianza (Alianza por la Justicia, el Trabajo y la Educación). A Alianza capitalizou os votos dos eleitores insatisfeitos com o "menemismo", e venceu as eleições presidenciais de 1999. Foram eleitos De la Rúa, da UCR, para a Presidência, e “Chacho” Álvarez, da Frepaso, para vice-Presidente, recebendo $48,37 \%$ dos votos válidos (ARGENTINA, 2008b).

\section{INSTABILIDADE POLÍTICA PÓS-MENE- MISMO, CRISE DE 2001 E RETORNO DO JUSTICIALISMO (1999-2007)}

O crescimento político da Alianza deveu-se à dissipação do clima de emergência econômica, trazendo à tona o descontentamento da população em relação às práticas de corrupção presentes no meio político. A promessa de manutenção da con-

\footnotetext{
10 A Frepaso reunia dissidentes do justicialismo, do radicalismo da Unidade Socialista etc. Dentre seus líderes, destacava-se o ex-peronista Carlos "Chacho" Alvarez, que havia abandonado o Partido Justicialista em virtude de desentendimentos em relação à condução da política econômica de Menem. Álvarez liderou um grupo de deputados conhecido como "Os Oito", uma das únicas vozes dissonantes dentro do peronismo em relação ao Plano de Convertibilidade na gestão Menem (ROMERO, 2005).
} 
versibilidade e o apoio às reformas de mercado permitiram que até mesmo os grupos empresariais superassem seus medos em relação a eventuais turbulências associadas à saída do peronismo ("menemista") do poder. Os setores prejudicados pelas reformas econômicas, por seu turno, acreditaram que a Alianza ofereceria algumas correções aos rumos da política econômica, revertendo e/ou compensando suas perdas (CHERESKY, 1998).

Contudo, o governo De la Rúa não foi capaz de cumprir a promessa de "renovação" dos valores republicanos, tampouco de reversão do quadro de deterioração das condições econômicas e sociais que atravessava o país. A Alianza enfrentou grandes problemas para converter-se em uma coalizão governante.

A Frepaso abrangia diversas agremiações políticas que dificilmente poderiam coordenar suas ações. Suas contradições acentuavam-se conforme alguns dirigentes partidários passavam a reforçar o apoio ao neoliberalismo (NOVARO, 2003). Pelo lado da UCR, o Presidente De la Rúa tornava-se cada vez mais isolado. A concentração de poder nas mãos do Presidente, justificada pela crise, serviu apenas para acentuar seu isolamento político (NOVARO, 2006).

A crise da coalizão tornou-se patente com a renúncia do vice-Presidente “Chacho” Álvarez, em 2000, após liderar uma campanha de denúncia de casos de suborno no Senado, vinculados à aprovação da reforma trabalhista. Sem encontrar apoio do Presidente - que, pelo contrário, ofereceu suporte aos acusados -, o vice-Presidente optou por abandonar o governo, mas manteve formalmente seu apoio à Alianza (idem, p. 286-287).

A recessão econômica, somada à incapacidade do governo De la Rúa em atender às demandas sociais, levou a um clima de insatisfação popular. A população tomou as ruas, no final de 2001, em protestos que expressavam sua insatisfação com a classe política, simbolizada pela frase "que se vayan todos”, de rejeição à classe política. Nas eleições legislativas de outubro de 2001, a derrota da Alianza foi contundente (ESCOLAR et alii, 2002). Entre 1999 e 2001, a Alianza perdeu 59,7\% de votos (TORRE, 2003).

Os problemas da coalizão governante agravarse-iam nos meses seguintes, com a deterioração das condições financeiras. O governo enfrentava problemas nas contas públicas, mas não havia vontade ou apoio político para um eventual abandono do Plano de Convertibilidade.

No final de 2001, o governo De la Rúa anunciou o corralito, estopim para que a população tomasse as ruas em manifestações contra mais de três anos de recessão e taxas de desemprego de quase $20 \%$. A população organizou suas manifestações por meio de piquetes - organizados por desempregados - e "panelaços" (MOCCA, 2005). A pressão popular levou à renúncia do Presidente De la Rúa (MUSSA, 2002, p. 50).

Muitos analistas enfatizam que a crise de 2001 poderia ter sido evitada caso o Plano de Convertibilidade houvesse sido abandonado. No entanto, o regime cambial em vigor contava com amplo apoio dos diversos atores sociais: um eventual abandono da paridade cambial e a conseqüente desvalorização do peso levariam a perdas para famílias, empresas e o próprio Estado, endividados em dólares. Havia, portanto, um consenso em torno da conversibilidade, que dificilmente seria desfeito.

Ainda assim, uma coalizão política rival articulava-se durante a crise: no âmbito da Unión Industrial Argentina (UIA), articulava-se uma coalizão opositora que visava substituir o regime de conversibilidade por um modelo centrado em um tipo de câmbio desvalorizado, que encareceria os bens importados, favorecendo a produção doméstica.

A renúncia de De la Rua, em dezembro de 2001, provocou um a vacância simultânea da Presidência e da vice-Presidência. A Assembléia Legislativa reuniu-se para escolher seu sucessor. O escolhido foi Adolfo Rodríguez Saá (PJ), então Governador de San Luis, mediante um acordo segundo o qual ele manter-se-ia no poder por 90 dias, até a realização das novas eleições presidenciais. No entanto, Rodríguez Saá mostrou o desejo de romper o acordo e cumprir o restante do mandato de De la Rúa. Em apenas uma semana, em meio às divergências internas no $\mathrm{PJ}$ e aos protestos populares, ele foi derrubado. Em sua curta passagem pela Presidência, Rodríguez Saá deixou sua marca. Declarou a moratória da dívida pública argentina, mas recusou-se a abandonar o regime de conversibilidade (TORRE, 2004).

Em $1^{\circ}$ de janeiro de 2002, a Assembléia Legislativa indicou Duhalde (PJ) para ocupar pro- 
visoriamente a Presidência, ocupando o cargo durante todo o restante do mandato de De la Rúa. Duhalde valeu-se de sua base de apoio para realizar a grande ruptura que se fazia necessária. Dentre suas primeiras iniciativas, destaca-se a declaração do fim do Plano de Convertibilidade (idem, p. 172-175).

Duhalde assumiu a tarefa de estabilizar o país nas esferas política, econômica e social. Inicialmente, a equipe econômica (liderada pelo Ministro da Economia Jorge Remes Lenicov), oscilou entre a heterodoxia e a ortodoxia, cedendo às pressões de atores externos. Em maio de 2002, face o fracasso das tentativas iniciais de estabilizar a economia, Lenicov foi substituído por Lavagna, responsável por lançar as bases necessárias para a recuperação econômica, que teve início no segundo semestre de 2002.

O debate sobre a reforma foi levado a cabo somente com o colapso do regime de conversibilidade. Nesse contexto, Duhalde buscou formar uma coalizão que apoiasse as medidas emergenciais, envolvendo uma aliança entre governo, empresários e sindicatos, além de reintegrar os novos atores sociais dentro dos canais de contato oficiais entre o Estado e a sociedade. No âmbito legislativo, essa coalizão era composta por uma ampla base de apoio - que incluía desde políticos da UCR até partidários de Menem - cujos únicos pontos de concordância eram o fim do Plano de Convertibilidade e do modelo neoliberal adotado na década de 1990 (FAUCHER \& ARMIJO, 2004).

Um fator que tornava ainda mais complexa a construção de um ambiente necessário para a consecução das medidas reformistas era a reduzida legitimidade de origem do Presidente, figura marginalizada dentro do próprio partido e não eleita pelo voto popular, mas por indicação do Congresso. A debilidade política de Duhalde era tal que o Presidente chegou a condicionar sua permanência no cargo ao cumprimento de condições consideradas necessárias para se dar prosseguimento às negociações com o FMI (MALAMUD, 2002, p. 1).

No entanto, a fragilidade do Presidente acabou por converter-se em um recurso importante para a redução das expectativas dos atores sociais e pela conseqüente emergência de um apoio difuso à governabilidade em um contexto emergencial (BOSOER, 2004). O Congresso apro- vou a Lei de Emergência Pública e Reforma do Regime Cambial (no ano de 2002), que concedeu ao Presidente um significativo grau de autonomia nas relações com as empresas privatizadas. A quebra de contratos foi duramente criticada pelos representantes das empresas prestadoras de serviços de serviços privatizados (Argentina's Economy: Poised for Growth?, 2003). Duhalde cedeu às pressões destas empresas ${ }^{11}$, permitindo alguns reajustes tarifários, como nos setores de energia e gás (AZPIAZU \& SCHORR, 2003, p. 5).

Não se deve desprezar o fato de o fim do regime de conversibilidade ter resultado na tentativa de desenvolver novas relações contratuais com as empresas privatizadas, revertendo alguns dos privilégios concedidos na década de 1990 pelas gestões anteriores (idem, p. 3). Além disso, a "pesificação assimétrica" consistiu na tentativa de distribuir os custos da desvalorização, de forma mais ou menos eqüitativa, entre bancos, poupadores e devedores (NOVARO, 2006).

Os rumos da política cambial pós-conversibilidade foram definidos por Lavagna, que tomou posse como Ministro da Economia em maio de 2002. A política cambial passou a girar em torno da estratégia de manutenção do câmbio competitivo - na qual a cotação do peso era estimada em torno de três unidades por dólar. Essa equivalência coincidia com as demandas preexistentes de alguns setores da indústria nacional que haviam perdido competitividade sob o regime de conversibilidade. A postergação da renegociação dos contratos dos serviços públicos privatizados também esteve sempre próxima das demandas dos empresários industriais, que temiam os impactos negativos dos reajustes tarifários. Por fim, o congelamento dos salários convergia com as expectativas dos empresários nacionais (AZPIAZU \& SCHORR, 2003, p. 3). Deve-se ter em vista que

11 As empresas prestadoras de serviços públicos privatizados adotaram como estratégias: pressão sobre os governos de seus países de origem que, recorrendo ao FMI, poderiam pressionar o governo argentino, além das ameaças de encerrar suas atividades no país, reduzir investimentos ou dispensar funcionários, declarar a moratória de suas dívidas e do recurso a tribunais internacionais (previstos nos Tratados Bilaterais para a Promoção de Investimentos Estrangeiros firmados pela Argentina). Muitas empresas descumpriram ainda as cláusulas contratuais referentes ao nível de qualidade dos serviços prestados e negaram-se a pagar as multas devidas (AZPIAZU \& SCHORR, 2003, p. 6). 
em virtude do contexto de mergência econômica, os sindicatos apoiaram o congelamento salarial, somando-se aos empresários na nova coalizão de apoio ao governo Duhalde (NOVARO, 2006).

Mesmo com a retomada do crescimento econômico, diveras questões foram deixadas pendentes, como a renegociação dos contratos com empresas prestadoras de serviços públicos privatizados, a recapitalização dos bancos, a reestrutração da dívida em moratória e a inclusão da população desempregada no mercado de trabalho.

Duhalde não possuía legitimidade política para definir a nova relação de "ganhadores" e "perdedores" do novo contexto econômico, em virtude de exercer o cargo provisoriamente apoiado por uma ampla e heterogênea coalizão política. Tendo que enfrentar novas mobilizações e manifestações sociais, ele optou por antecipar as eleições presidenciais, previamente marcadas para dezembro de 2003, para maio daquele ano.

O ex-Presidente Menem surgia como provável candidato peronista para a disputa presidencial de 2003. Duhalde, a fim de evitar que o PJ lançasse seu adversário político como candidato, orquestrou uma manobra política que anulou as eleições internas do partido. Dessa forma, três candidatos peronistas concorreram à Presidência, sem o apoio formal do partido: Menem, Kirchner e Rodríguez Saá. Kirchner, o desconhecido Governador da província de Santa Cruz, teve sua campanha embasada no apoio do então Presidente $^{12}$ (TORRE, 2004).

Os resultados iniciais indicavam que as eleições seriam decididas no segundo turno, entre Menem (que recebeu $24,45 \%$ dos votos) e Kirchner (escolhido por 22,24\% do eleitorado) (ARGENTINA, 2008b). As pesquisas de opinião revelavam que o segundo turno polarizaria o voto “anti-Menem". Menem, em vista a uma iminente derrota nas urnas, desistiu de sua candidatura, permitindo que Kirchner fosse declarado vencedor (TORRE, 2004, p. 180-181).

12 Kirchner foi o terceiro e último nome procurado por Duhalde para compor a chapa para as eleições presidenciais (BONVECCHI, 2004). Anteriormente, surgiram como candidatos prováveis os governadores das províncias de Santa Fe, Carlos Reutemann, e de Códoba, Juan Manuel de la Sota.
Kirchner era considerado, no momento de sua chegada ao poder, pelos observadores políticos e pela população em geral, como um "governante fraco, submetido aos interesses de seu único apoio político e suscetível a ficar enredado [...] nas virulentas e intermináveis disputas internas do peronismo.” (BONVECCHI, 2004, p. 189). Ele havia tomado posse de forma inesperada, sem sustentação popular ou apoio do próprio partido (TORRE, 2004).

A prioridade política do novo Presidente, logo que tomou posse, foi estabelecer sua liderança junto ao partido e à opinião pública, além de construir uma base de sustentação sólida no Congresso (BONVECCHI, 2004, p. 189-195; BONVECCHI \& GIRAUDY, 2007, p. 36-39).

Para De Luca (2007), o governo Kirchner foi caracterizado pela concentração de quase todas as decisões políticas nas mãos do Presidente, apoiado somente por um conjunto pequeno de colaboradores. Quando alguns desses passaram a oferecer-lhe resistência - como Lavagna, contrário à politização de delicadas questões econômicas, como a renegociação da dívida em moratória -, o Presidente optou pelo seu afastamento. Além disso, conseguiu que o Congresso delegasse-lhe alguns poderes em relação ao orçamento e recorreu abusivamente aos DNUs.

Kirchner buscou consolidar sua liderança política afastando-se da sombra do ex-Presidente Duhalde, aproximando-se de políticos de distintas origens partidárias, mas com os quais possuía semelhanças ideológicas. Essa estratégia ficou conhecida como "transversalidade" (BONVECCHI, 2004 p. 195).

A coalizão "transversal” construída por Kirchner englobou setores peronistas e nãoperonistas, aí incluídos ex-membros da Frepaso, nacionalistas de esquerda, social-liberais e socialdemocratas (UCR, PS, PI e Democracia Cristã), grupos "piqueteros" e sindicalistas com raízes peronistas (GODIO, 2006). A formação dessa coalizão nunca expressou-se em um programa de governo sólido (MALAMUD, 2004).

A estratégia de Kirchner em relação aos grupos sociais em torno dos temas prioritários da agenda pública - reajustes de salários e preços, por exemplo - ocorreram a partir de canais de articulação ad hoc. Não houve, portanto, uma tentativa de incoporar as demandas dos diversos ato- 
res sociais no sentido de formação de um consenso político a respeito da política econômica. Nesse sentido, a relação entre "ganhadores" e "perdedores” sob o modelo de crescimento apoiado no "câmbio competitivo" não se traduziu no apoio automático ao Presidente.

\begin{tabular}{|c|c|c|}
\hline Beneficiados & Não-beneficiados & Sem mudança \\
\hline Setor exportador & $\begin{array}{l}\text { Detentores de títulos da } \\
\text { divida argentina. }\end{array}$ & $\begin{array}{l}\text { Províncias (apesar da adoção do ajuste } \\
\text { fiscal, beneficiam-se do aumento da } \\
\text { arrecadaçẫo associada ao c rescimento } \\
\text { econômico e da manutençẫo dos baixos } \\
\text { salários dos servidores). }\end{array}$ \\
\hline Setor industrial & $\begin{array}{c}\text { Setor de serviços } \\
\text { privatizados (congelamento } \\
\text { das tarifas). }\end{array}$ & $\begin{array}{c}\text { Setor bancário (apesar das perdas } \\
\text { iniciais, que inibiram a concessẫo de } \\
\text { crédito, rec eberam compensaçốes } \\
\text { efetuadas pelo governo). }\end{array}$ \\
\hline $\begin{array}{l}\text { Governo central (aumento } \\
\text { da arrecadaçẫo e } \\
\text { manutençẫo de baixos } \\
\text { índices salariais). }\end{array}$ & $\begin{array}{c}\text { Trabalhadores (manutençẫo } \\
\text { de bakos salários, apesar } \\
\text { da política de acordos } \\
\text { salariais). }\end{array}$ & \\
\hline
\end{tabular}

Fonte: autora.

Para além das linhas gerais do modelo econômico (câmbio competitivo, austeridade fiscal e políticas de assistência aos desempregados), devese ter em vista que outras medidas tomadas pelo governo (política de preços, tributação sobre as exportações etc.) geraram descontentamento entre aqueles que, à primeira vista, pareciam beneficiar-se com o novo modelo econômico.

$\mathrm{O}$ apoio do empresariado, particularmente da Unión Industrial Argentina (UIA) nunca expressou-se em um debate formalmente institucionalizado em torno de um plano estratégico para a política econômica. Ele dava-se a partir de negociações ad hoc, ocorridas em resposta a probemas conjunturais. Alternaram-se períodos de confrontação aberta e períodos de diálogo seletivo com grupos empresariais (BOSCHI \& GAITÁN, 2008).

Os bancos nacionais, por seu turno, também se desvincularam dos bancos estrangeiros tendo em vista a cooperação com o governo federal (BONVECCHI, 2004).

A política antiinflacionária resultou em reações adversas entre os atores sociais. O controle de preços, apesar de criticado por setores empresariais, não encontrou resistência formal. Pelo contrário, a UIA apoiou-a abertamente. O setor agro-pecuário, por sua vez, manifestou sua oposição: associações do setor realizaram paralisações no abastecimento
(BONVECCHI \& GIRAUDY, 2007, p. 30). As retenções (tributações) sobre as exportações também despertaram a oposição desse setor.

Já no que diz respeito às relações com os sindicatos, Kirchner buscou cooperar com essas organizações, sem, contudo, incorporar quaisquer de seus membros ao governo (GODIO, 2006). Oscilaram períodos de cooperação e de confrontação entre governo e sindicatos (BONVECCHI \& GIRAUDY, 2007).

No que diz respeito ao reajuste das tarifas dos serviços públicos privatizados, o governo adotou a estratégia de postergar as negociações. Apesar dos freqüentes recursos junto a cortes internacionais de arbitragem, não se chegou a uma solução para o caso da reelaboração do arcabouço legal de operação dessas empresas, tampouco quanto aos reajustes tarifários. Os empresários desse setor mantiveram sua oposição ao governo durante todo o mandato de Kirchner.

\section{O GOVERNO ARGENTINO E O FUNDO MONETÁRIO INTERNACIONAL}

A crise de 2001 consistiu em um marco nas relações entre a Argentina e o FMI. Ao longo da década de 1990, o governo Menem havia logrado construir uma relação estreita com o Fundo que, após hesitações iniciais, apoiou o Plano de Convertibilidade até as vésperas de seu colapso. Com a chegada de Duhalde à Presidência em 2002, 
o governo argentino oscilou entre uma perspectiva de maior ou menor aproximação em relação o Fundo, objetivando assinar o acordo considerado necessário para assegurar a estabilidade econômica durante o período de transição política. O pessoal do organismo esperava que, após as eleições de 2003, fossem dados contornos mais precisos às reformas previstas no acordo transitório. Kirchner, entretanto, chegou ao poder com uma proposta de política econômica diferente daquela tradicionalmente apoiada pelo Fundo. Além disso, sua estratégia para ampliar sua base de apoio interno (popular) incluía críticas ao FMI, atribuindo-lhe parte da responsabilidade pela bancarrota do país na virada do século.

Menem recebeu forte apoio político do FMI durante toda a sua gestão. As reformas neoliberais levadas a cabo por seu governo refletiam-se em critérios estabelecidos pelo mainstream do pensamento neoliberal, que apregoava a redução da atuação do Estado como solução para a promoção do crescimento econômico.

Durante a década de 1990, a Argentina havia sido retratada pelo FMI como um modelo a ser seguido pelos demais países em desenvolvimento na direção das reformas neoliberais. De acordo com o então Ministro da Economia, Cavallo, as reformas econômicas implantadas durante o governo Menem foram elaboradas internamente, sem qualquer influência do FMI. Ele reconhece que algumas das medidas adotadas coincidiam com as "receitas" do organismo, mas destaca que outras - em particular a política de juros elevados e a reforma monetária que instituiu o regime de conversibilidade cambial - iam de encontro às suas recomendações (CAVALLO, 2003).

Segundo Cavallo, o governo norte-americano - na época sob a gestão George Bush (pai) - "influenciou de maneira decisiva” a opção de Menem de abandonar as políticas econômicas tradicionalmente peronistas (idem, p. 4. Tradução e itálico nossos). Essa influência não ocorreu diretamente sobre a elaboração da política econômica, mas por meio da estratégia de política externa de então, que pretendia manter uma relação especial entre a Argentina e os Estados Unidos ${ }^{13}$. O governo obteve o apoio externo necessário para a execução

13 A condução da política externa do governo Menem, conhecida como "Nova Política Exterior”, tinha como núcleo a definição do interesse nacional em termos de desen- das reformas econômicas: pressionado pelo governo norte-americano, o FMI passou a cooperar com o governo argentino, inclusive por meio da concessão de empréstimos necessários para a implantação do programa reformista (idem). O governo norte-americano também expressou seu apoio ao Plano de Convertibilidade com a decisão de tornar a Argentina elegível para reestruturar sua dívida no marco do Plano Brady (STARR, 1997).

O apoio declarado do FMI ao Plano de Convertibilidade, contudo, só veio à tona após a crise mexicana, em 1994-1995. A recuperação da economia argentina após um breve período recessivo, mantendo-se o vigor do modelo cambial fixo, foi decisiva para a modificação na orientação do FMI. A partir de então, o apoio do organismo ao modelo econômico argentino seguiria irrestrito até o auge da crise financeira de 2001 (BLUSTEIN, 2006).

Na Argentina, diferente de outros países em desenvolvimento, a presença de missões do FMI foi constante, não se restringindo a momentos de crise. Salienta-se que, no momento em que a economia expandia-se, a assistência não dizia respeito à concessão de pacotes de ajuda financeira. A atuação do FMI voltou-se predominantemente para a concessão do aval político necessário para elevar a confiança do investidor (STARR, 1997)

Como visto anteriormente, a coalizão de sustentação ao governo Menem era composta por grandes conglomerados nacionais e estrangeiros, credores e sindicatos. Nesse sentido, o processo decisório em torno da agenda econômica concentrou-se em reformas favoráveis a esses grupos socioeconômicos: privatizações, abertura comercial e desregulamentação financeira. Todas essas reformas receberam o apoio irrestrito do FMI.

volvimento econômico. Foi orientada pelo chamado "realismo periférico”, que pretendia a re-inserção da Argentina no mundo desenvolvido, que teria abandonado por decisão própria em um dado momento histórico. Esse abandono seria ilustrado pela adoção de uma política de competição e confrontação com os Estados Unidos. Segundo essa perspectiva, o atraso em relação aos países desenvolvidos poderia ser revertido por meio de uma política exterior que pretendesse a construção e manutenção de uma aliança com os Estados Unidos, a fim de manter com este uma relação preferencial. Nas palavras do então Ministro das Relações Exteriores, Guido di Tella, deveriam ser estabelecidas "relações carnais” com os Estados Unidos (BERNAL-MEZA \& QUINTANAR, 2001; ARANDA, 2004). 
No entanto, segundo os representantes do organismo, era necessário avançar ainda mais no processo reformista, incluindo reformas nas relações trabalhistas e na previdência. Entretanto, as propostas neoliberais, pelo menos nessas áreas, encontravam grande resistência em meio aos trabalhadores, diretamente afetados por essas medidas. Os sindicatos consistiam em um pilar de sustentação do governo, indissociável do peronismo. Por isso, a reforma da previdência foi aprovada somente de modo parcial, mantendo-se um regime dual de previdência pública e privada. A reforma trabalhista, por sua vez, foi amplamente resistida.

Para o FMI, a aprovação dessas reformas era essencial para o estímulo ao investimento no país e para o saneamento das contas públicas a médio prazo. Em relação a essa última questão - as finanças públicas -, o FMI também defendia a consecução de ajustes fiscais. Essa proposta, contudo, era resistida pelo governo Menem. O saneamento das contas públicas dependia ainda de modificações no sistema de co-participação dos recursos entre governo central e províncias. Entretanto, configuração do sistema político argentino, no qual os líderes provinciais exercem poder de veto, constrangia as ações do governo Menem em torno desse tipo de reforma.

O enfraquecimento da liderança de Menem ao longo do seu segundo mandato esfriou o esforço reformista. Ainda assim, o apoio do FMI foi mantido, traduzindo-se na revisão sistemática das metas fiscais, permitindo os déficits fiscais. Esse comportamento deve ser compreendido no contexto da pressão política exercida pelo governo dos Estados Unidos, que apoiava o governo argentino na execução de "políticas muito simpáticas ao sistema bancário internacional” (KLAGSBRUNN, 2006, p. 10.

Com a eleição de De la Rúa, o apoio ao modelo neoliberal e ao Plano de Convertibilidade foi mantido. O FMI manteve seu respaldo ao governo De la Rúa, concedendo um novo pacote de ajuda financeira em 2000, a chamada "blindagem financeira”. Com esse pacote, pretendia-se manter o pagamento dos juros da dívida em dia e atrair os investidores (DE LA RUA'S SURPRISE FOR ARGENTINA, 2000). No entanto, a sucessiva liberação de recursos financeiros não foi capaz de recuperar o acesso do país ao mercado financeiro (MUSSA, 2002).
De la Rúa chegou ao poder em momento de recessão econômica e, livre das amarras do movimento sindical - o radicalismo não mantém vínculos orgânicos com o movimento sindical, tal como o peronismo -, viu-se livre para aprovar a reforma trabalhista, em 2000. Segundo os defensores do neoliberalismo, aí incluído o FMI, a reforma reduziria o peso dos encargos trabalhistas e estimularia o investimento. A longo prazo, o crescimento econômico reduziria as elevadas taxas de desemprego no país que eram atribuídas, justamente, à rigidez das relações trabalhistas.

A reforma trabalhista foi marcada por denúncias de suborno para a sua aprovação no Senado. Essas denúncias foram lideradas pelo próprio vicePresidente, “Chacho” Álvarez, que optou por abandonar o governo (AFTER ALVAREZ: ARGENTINA'S WOBBLING ALLIANCE, 2000).

De la Rúa viu-se enfraquecido politicamente. Eleito a partir de uma plataforma de defesa dos ideais republicanos e de combate à corrupção, seu governo perdeu legitimidade frente à opinião pública. Os desafios do seu governo, contudo, permaneciam enormes: a recessão econômica aprofundava-se e o mercado financeiro permanecia volátil. Para conter a recessão e recuperar a confiança dos investidores, De la Rúa estabeleceu como prioridade da agenda pública a defesa do Plano de Convertibilidade e a manutenção do pagamento da dívida pública.

Salienta-se que, com o prosseguimento do modelo de crescimento baseado na captação de poupança externa, a confiança do investidor adquire centralidade para a sustentabilidade da economia. Sob um regime de câmbio fixo, o Presidente não poderia recorrer aos instrumentos da política monetária e cambial para conter a recessão. Restou-lhe a opção pelo ajuste fiscal. Cortes de gastos e investimentos públicos, que chegaram a incluir reduções na folha de pagamento (cortes de salários, pensões e aposentadorias) foram os meios empregados para assegurar-se o pagamento da dívida pública e o repasse de recursos às províncias. Em um contexto recessivo e de empobrecimento da população, o corte de gastos sociais contribuiu para elevar o descontentamento popular.

Enfraquecido internamente, De la Rúa contava com o apoio externo para manter suas políticas emergenciais, formando um equilíbrio político frágil que o mantinha no poder. O prossegui- 
mento da situação econômica e a rejeição popular à classe política levaram à derrota expressiva da Alianza nas eleições legislativa de outubro de 2001.

No âmbito externo, as condições também modificavam-se. A vice-Diretora-Gerente do FMI, Anne Krueger, apresentou, no segundo semestre de 2001, a proposta de criação de um novo modelo de reestruturação de dívidas soberanas, na qual o FMI adquiria centralidade na intermediação das relações entre países devedores e credores privados. Segundo o então Ministro Cavallo, o anúncio da proposta, embora não diretamente relacionada com o caso argentino, alimentou a percepção dos investidores de que o fim do Plano de Convertibilidade e a moratória da dívida estavam próximos.

Deve-se frisar que a proposta de Krueger não foi aceita nem pelos países-membros do FMI nem pelos credores privados. O Secretário do Tesouro norte-americano, Paul O’Neill, propôs um mecanismo rival, que reduzia o papel do FMI na intermediação das relações entre credores e países devedores, oferecendo uma proposta "contratual”. Segundo a sua proposta, a emissão de títulos da dívida vincular-se-ia a cláusulas referentes a eventuais casos de moratória (MENDONÇA, 2003).

Essa proposta insere-se no viés ideológico dos membros do governo Bush, favoráveis a uma abordagem ainda mais liberal das relações econômicas. Para o governo Bush, a atuação do FMI como prestamista de última instância incentivava o comportamento irresponsável de países devedores e de credores privados, isto é, incentivava o risco moral. Segundo sua avaliação, o dinheiro dos contribuintes norte-americanos não deveria ser empregado em socorro a governos que adotaram medidas fiscais imprudentes que acabaram por levar à insolvência da dívida pública. Além disso, o FMI não deveria agir em defesa de investidores que compraram papéis de alto risco em busca de retornos exorbitantes. Credores e devedores agiram por sua própria conta e risco e, portanto, deveriam ser responsabilizados pelos seus atos (HELLEINER, 2005).

A redefinição dos interesses no âmbito internacional levou o FMI a determinar o fim do apoio à Argentina, dada a insustentabilidade do Plano de Convertibilidade e do perfil do endividamento público argentino. A concessão de novos recursos à Argentina, além de não resolver os problemas fun- damentais do modelo econômico, levaria somente ao aumento da exposição financeira do FMI em relação ao país, que poderia ver os argentinos negarem-se a pagar suas dívidas.

A retirada do apoio externo concretizou-se em novembro de 2001. A corrida aos bancos prosseguia, levando o governo De la Rúa a anunciar o corralito, estopim para a mobilização popular que levou à sua renúncia.

Seu sucessor, Duhalde, buscou restabelecer relações com o FMI logo após tomar posse. O apoio externo era considerado fundamental para o retorno do fluxo de financiamento externo. Esse fluxo assumia centralidade em razão do tamanho reduzido do mercado financeiro doméstico no país. Sem investimento, a atividade produtiva não poderia retomar seu crescimento (FERNÁNDEZ ALONSO, 2006).

A reaproximação com o FMI, como era de esperar-se, ocorreu em um contexto conturbado. As primeiras iniciativas tomadas por Duhalde, como a introdução do câmbio dual - conhecido como "pesificação assimétrica" - e o congelamento das tarifas dos serviços públicos privatizados foram algumas das medidas criticadas pelo pessoal do FMI. Na sua avaliação, essas medidas contribuíam para reduzir ainda mais a confiança dos investidores nos setores financeiro e produtivo, em um contexto de moratória. Segundo essa perspectiva, bancos estrangeiros e empresas prestadoras de serviços públicos privatizados não somente deixariam de investir na Argentina, como poderiam deslocar suas atividades para outros países (idem).

O governo Duhalde cedeu às pressões do FMI e unificou a taxa de câmbio. Em seguida, a cotação do dólar disparou no mercado de câmbio, gerando perspectivas negativas quanto à recuperação da economia argentina. Segundo o próprio FMI, a Argentina atravessaria um longo período de recessão econômica e de hiperinflação (idem).

A deterioração do cenário econômico levou à queda do então Ministro da Economia, Remes Lenicov. Para substituí-lo, Duhalde indicou Roberto Lavagna, crítico antigo do regime cambial fixo vigente na década de 1990 e do modelo econômico baseado na captação de poupança externa. Lavagna introduziu um novo modelo cambial, conhecido como "câmbio competitivo", visando estimular as exportações e promover a industrialização substitutiva de importações. 
A manutenção do câmbio desvalorizado e o congelamento das tarifas dos serviços públicos privatizados atendiam a demandas antigas do empresariado nacional, particularmente de setores ligados à Unión Industrial Argentina. Esses setores integraram-se à ampla e heterogênea coalizão de apoio ao governo Duhalde.

Os resultados do novo modelo cambial não foram imediatos. Diante do prosseguimento da crise, o FMI continuou pressionando o governo Duhalde durante todo o ano, para que fossem introduzidas medidas mais enérgicas para a reestruturação do marco regulatório de operação das empresas prestadoras de serviços públicos, enfatizando a necessidade de reajustarem-se as tarifas. Também demandava pela aceleração das compensações aos bancos prejudicados pela “pesificação" assimétrica, mesmo sob o argumento do governo Duhalde de que essas medidas já vinham sendo implementadas.

A introdução de tributos sobre as exportações de determinados bens agro-pecuários também foi condenada pelo FMI. Na sua avaliação, essa tributação inibia o crescimento das exportações argentinas, que seriam o pilar do novo modelo de crescimento econômico do país. Para os representantes do governo Duhalde, tratava-se de uma incoerência na posição do FMI, que pressionava pelo saneamento das contas públicas.

Na área fiscal, o FMI demandava pela reforma das relações intergovernamentais, incluindo a reforma do sistema de co-participação de recursos com as províncias. Em um contexto no qual os governadores provinciais adquiriam centralidade nas relações políticas, essas proposta não encontrava entrada na agenda pública do país.

A frágil liderança de Duhalde, que ocupava a Presidência e respondia aos interesses de uma ampla coalizão de apoio, impedia a definição de uma estratégia consistente nas negociações com o FMI. O Presidente oscilava entre o apoio às demandas do organismo - por diversas vezes, Duhalde atrelou sua permanência no cargo ao atendimento, pelo Congresso, de demandas do FMI e à confrontação aberta com o organismo, por não apoiar as medidas do governo na área econômica.

Os governadores provinciais assumiram centralidade nas relações com o FMI. Sua atuação tornou-se clara já no começo de 2002, quan- do Duhalde havia optado por romper relações com o FMI. Muitos governadores provinciais pressionaram o governo central para que as negociações com o Fundo fossem retomadas. Nesse contexto, firmou-se com os Governadores provinciais a chamada "Declaração dos Quatorze Pontos", documento que pretendia determinar a orientação da política econômica do país, atendendo a alguns dos reclamos do FMI (idem). Este documento expressava o poder dos Governadores provinciais vis-à-vis o Presidente, uma vez que ia na direção contrária daquela anunciada por Duhalde, que apontava para o afastamento em relação ao Fundo (NEW MAN, OLD WOES. 2002).

Mesmo com a retomada do diálogo, FMI endurecia progressivamente as "condicionalidades" associadas à aprovação de um acordo com o governo Duhalde (DUHALDE HEADS FOR THE DOOR, 2002). O organismo, enfraquecido politicamente, vacilava na definição de seus novos rumos de atuação. Preocupava-se com a redução da exposição financeira frente à Argentina e reduzia seu escopo de atuação a casos de crises domésticas que não possuíam potencial para gerar crises sistêmicas.

A atuação do governo norte-americano, sob a gestão Bush, influenciou de modo decisivo as negociações entre o governo argentino e o FMI. Embora o pessoal do organismo pretendesse endurecer as condicionalidades associadas à assinatura de um acordo com a Argentina, a linha ideológica assumida pelo governo dos Estados Unidos determinou a modificação da atuação do FMI, em favor da redução de sua intromissão em assuntos ligados à política econômica doméstica (HELLEINER, 2003).

A legitimidade do FMI sofreu um novo abalo com a retomada do crescimento econômico argentino, não prevista pelo organismo. Em 2003, o acordo provisório acabou por ser firmado, contrariando as recomendações do pessoal do organismo. A decisão pelo acordo foi tomada pelos países do G-7, especialmente Estados Unidos, França e Itália. O acordo firmado não definia metas relativas às reformas estruturais, deixadas pendentes para as negociações entre o FMI e o Presidente que viesse a suceder Duhalde (THE IMF CLIMBS ABOARD; ARGENTINA'S ECONOMY, 2003).

As eleições, marcadas para maio de 2003, definiram a vitória de Kirchner. Durante sua gestão, a nova coalizão governante ganhou contornos mais 
precisos, e a concessão de centralidade ao setor industrial voltado para o mercado doméstico consistiu a base de sustentação do governo Kirchner.

A linha de exclusão de setores socioeconômicos na coalizão de sustentação ao governo Kirchner também adquiriu contornos mais precisos: bancos e empresas prestadoras de serviços públicos privatizados na década de 1990 sofreram confrontação aberta de Kirchner. O Presidente responsabilizou-os pela sustentação do modelo econômico neoliberal que culminou na crise de 2001. Credores da dívida também foram incitados a assumir responsabilidade pela compra de papéis da dívida argentina, considerados de alto risco, em razão dos retornos propiciados pela elevada taxa de juros atrelada os mesmos.

Esses atores perderam o poder de veto que possuíam sobre o sistema político argentino, o que exerceu influência decisiva sobre as relações entre o governo Kirchner e o FMI, defensor dos interesses de atores com vínculos internacionais ${ }^{14}$.

A tensão entre o governo Kirchner e o FMI em torno dessas questões ficou patente durante as negociações. Quando Köhler esteve na Argentina, em junho de 2003, o Presidente Kirchner declarou ao Diretor Gerente do Fundo que a prioridade do governo era o crescimento econômico, e não o ajuste fiscal. Além disso, garantiu que só firmaria acordos que fosse capaz de cumprir e, igualmente importante, disse a Köhler que o FMI era em grande parte responsável pela crise argentina (FIRST BLOWS, 2003).

\footnotetext{
14 Produtores de bens agro-pecuários também foram sistematicamente excluídos dos canais de diálogo com o governo Kirchner. Esses atores sentiam-se prejudicados pela manutenção das "retenções", introduzidas no governo Duhalde, e pela política de congelamento de preços dos alimentos no mercado doméstico. Em uma oportunidade, o governo Kirchner chegou a impedir a exportação de alguns gêneros alimentícios, a fim de conter os preços no mercado doméstico. Embora a oposição ruralista adquira centralidade para a compreensão das relações governo-oposição no kirchnerismo (aí incluída a gestão da esposa e sucessora de Néstor Kirchner, Cristina Fernández de Kirchner), as demandas desse setor possuem importância marginal para a análise das relações entre o governo Kirchner e o FMI. Uma explicação plausível é que o setor ruralista é essencialmente doméstico. O FMI esteve preocupado com grupos sócio-econômicos com vínculos internacionais: a maior parte dos bancos, empresas prestadoras de serviços públicos privatizados e credores eram estrangeiros.
}

Segundo o pessoal do FMI, o novo governo demorou a deslanchar sua estratégia para a recuperação econômica para o médio prazo: “O Presidente falou repetidamente sobre a importância que ele concede à Argentina distanciar-se de medidas econômica orientadas pela crise, e para normalizar as relações e políticas econômicas. No entanto, em questões sensíveis como tarifas de serviços públicos, compensações aos bancos e credores externos, muitos na Administração parecem ter adotado uma linha relativamente dura." (INTERNATIONAL MONETARY FUND, 2003, p. 7).

Segundo o pessoal do FMI, tratava-se de uma estratégia para a elevação da base de apoio popular do Presidente Kirchner (idem).

Não obstante as divergências, as negociações tiveram prosseguimento. Kirchner manifestou sua intenção em reestruturar a dívida pública em moratória desde 2001, considerada essencial para a retomada do financiamento à Argentina, sustentando seu forte crescimento econômico a médio e longo prazos.

As discussões centraram-se em torno da definição das metas de superavit fiscal, consideradas indispensáveis pelo FMI para a elaboração de uma proposta viável de reestruturação da dívida pública. No entanto, Kirchner negou-se a estabelecer a meta de superavit primário acima de 3\% do PIB, como requerido pelo FMI. O Presidente afirmou que só aceitaria acordos que pudesse cumprir: "[estreitando] seus próprios limites para a negociação, [ao anunciar] de antemão e publicamente a recusa a qualquer acordo que forçasse o país a restringir a demanda agregada, argumentando que isso interromperia o processo de reativação econômica. [...] Kirchner traçou, explicitamente, limites estritos ao poder negociador do ministro da Economia, Roberto Lavagna.” (BONVECCHI, 2004, p. 198).

Inicialmente, Kirchner adotou como estratégia anunciar que só entraria em negociação com os credores privados uma vez fechado o acordo com o FMI, elevando, ao mesmo tempo, seu poder de barganha vis-à-vis os negociadores do Fundo e os credores (HELLEINER, 2005).

O FMI ofereceu resistência: "Por um lado, o staff [...] manifestou seu pessimismo quanto à sustentabilidade do esquema de transferências externas proposto pela Argentina. Por outro lado, 
os membros europeus do Comitê Executivo do organismo exigiram, apoiados por outros países centrais, um nível maior de superávit, o reinício dos pagamentos aos credores privados em 2004 e um aumento de tarifas dos serviços públicos privatizados" (BONVECCHI, 2004, p. 198).

Quando as negociações em torno do acordo pareciam finalmente estar chegando a um consenso, o pessoal do Fundo re-introduziu algumas questões na pauta de discussões: "Havia sido estabelecido que as transferências líquidas de fundos entre as partes seriam equivalentes a zero, mas o FMI pretendia reduzir sua exposição em relação à Argentina e para isso exigia que houvesse demora entre os pagamentos do país e a devolução do dinheiro por parte do organismo de modo que a contabilidade do Fundo refletisse, em um dado momento, uma menor exposição. Nessa exigência, colocada no último momento, o Presidente encontrou a oportunidade para incluir plenamente o acordo com o FMI em sua cruzada regeneradora: instruiu Lavagna, que era contra isso, que recusasse o pedido do organismo, forçou o não-cumprimento da data de vencimento, encobriu suas causas repetindo argumentos já superados na negociação e, só quando esse ato tinha deixado claro seu papel de defensor da dignidade nacional frente aos credores e às empresas de serviços públicos, cedeu às exigências e assinou o acordo, elogiado por ser considerado como possível de ser cumprido" (idem, p. 199).

Lavagna recorreu ao governo norte-americano, solicitando a intervenção do Departamento de Tesouro para impedir o bloqueio das negociações, enquanto Kirchner, em 9 de setembro, optou por não pagar a dívida que vencia naquele dia. Os governos dos países do G-7 cederam à pressão do governo argentino, defendendo a aprovação do acordo no estágio em que se encontravam as negociações. A meta de superavit primário foi estipulada em 3\% do PIB, como requerido pelo governo, o que, na avaliação das autoridades argentinas, era compatível com as perspectivas de crescimento e redução da pobreza (idem).

Outro ponto considerado central pelo pessoal do Fundo - o aumento das tarifas dos serviços públicos privatizados - foi deixado de fora do acordo. Segundo os representantes do organismo, essa revisão incentivaria o retorno dos investimentos ao país, mas Kirchner argumentou que o Fundo não poderia fazer lobby para setores específicos. Também não estavam incluídas medidas de compensações aos bancos pela "pesificação" assimétrica (NÉSTOR KIRCHNER'S NIMBLE COOKERY, 2003).

As demandas por reformas estruturais não encontravam eco na agenda pública do governo Kirchner. Por isso, as revisões do acordo apontavam para o não cumprimento da promessa de definição das reformas estruturais. Deve-se salientar que as metas quantitativas definidas no acordo foram atingidas, geralmente com folga. $\mathrm{O}$ forte crescimento permitia a consecução dessas metas, ao mesmo tempo em que fornecia argumentos ao governo sobre a correção do modelo econômico adotado e o rechaço da necessidade de implementação de reformas.

A sistemática recusa do governo Kirchner a implementar estas reformas levou o FMI, apoiado pelos representantes do G-7, a vincular a aprovação da terceira revisão do acordo, em 2004, à imediata execução dessas reformas, além da melhoria na proposta de reestruturação da dívida e ao reajuste das tarifas dos serviços públicos privatizados, o que foi rejeitado pelo governo argentino (FERNÁNDEZ ALONSO, 2006).

O novo Diretor Gerente do FMI, Rodrigo Rato ${ }^{15}$, optou por adiar a aprovação dessa revisão. O governo Kirchner buscou novamente o apoio norte-americano, mas dessa vez suas tentativas não surtiram o efeito desejado. Em seguida, o Presidente optou por suspender o acordo com o FMI. Dessa forma, além de engajar-se no processo de reestruturação da dívida sem a intermediação do organismo, o país ainda iria deparar-se, no mesmo ano, com vencimentos de dívidas contraídas junto ao organismo, sem que houvesse os reembolsos previstos no programa suspenso. Pressionado, Rato visitou o país, chegando a um acordo (informal) com as autoridades argentinas: o pagamento das obrigações com o Fundo seria mantido, mas o processo de reestruturação da dívida não contaria com qualquer intermediação do organismo (idem). Em dezembro de 2005, o governo anunciou que pagaria antecipadamente suas dívidas com o Fundo.

15 Rato assumiu a Diretoria Executiva do FMI em 7 de junho de 2004. No hiato entre a gestão Köhler e Rato, Krueger exerceu as funções de Diretora Executiva do FMI. 


\section{CONCLUSÕES}

As relações entre a Argentina e o FMI apresentaram um ponto de inflexão a partir do governo Kirchner, eleito em 2003. Sua estratégia de negociação ganhou contornos nacionalistas, mais precisos em comparação àquela adotada por Duhalde, e determinou uma ruptura em relação às relações mantidas pelos governos Menem e De la Rúa em relação ao FMI. Essa modificação foi proporcionada por transformações nas ordens doméstica e internacional.

Nenhuma dessas esferas foi capaz de determinar a modificação da estratégia argentina nas negociações com o FMI durante o governo Kirchner. A inter-relação entre as dimensões doméstica e internacional é a chave da explicação dos fatores condicionantes dos resultados dessas negociações.

No âmbito doméstico, a emergência de uma nova coalizão governante, que concedeu centralidade ao setor empresarial voltado para o mercado doméstico, que apóia um modelo cambial competitivo, definiu quais interesses foram incluídos na agenda definida pelo governo Kirchner no engajamento das negociações com o FMI. Setores com vínculos internacionais, como credores da dívida, bancos estrangeiros e firmas prestadoras de serviços públicos privatizados perderam o poder de veto sobre o sistema político argentino, e viram seus interesses excluídos no processo decisório em matéria de política econômica.

No âmbito internacional, o FMI viu-se envolto por uma crise de legitimidade, derivada do fracasso do modelo neoliberal apoiado durante a década de 1990 e da mudança da orientação ideológica do governo George W. Bush em favor do laissez-faire. O escopo de atuação do FMI na concessão de pacotes de resgate financeiro, a intromissão na agenda econômica dos países em desenvolvimento e a intermediação das relações entre esses países e credores privados foi reduzido, em razão da orientação definida pelos Estados Unidos.

O FMI do começo do século XXI não é o mesmo da década de 1980: seu poder de barganha vis-à-vis os países em desenvolvimento, aí incluída a Argentina, reduziu-se significativamente. A necessidade de reforma do sistema financeiro internacional, tão defendida pelos países em desenvolvimento, ganham destaque nas discussões também nos países em desenvolvimento a partir da crise financeira de 2008. O FMI não é capaz de fornecer os instrumentos necessários para a resolução da crise. Os países do G-7 enfrentam grandes dificuldades para coordenar suas ações em um contexto de crise, não somente das finanças propriamente ditas, como também do regime financeiros internacional em sua dimensão normativa.

Roberta Rodrigues Marques da Silva (roberta.rms@gmail.com) é Mestre em Relações Internacionais pela Universidade Federal Fluminense (UFF) e professora do IBMEC-MG.

\section{REFERÊNCIAS BIBLIOGRÁFICAS}

ARMIJO, L. E. \& FAUCHER, P. 2002. We Have a Consensus: Explaining Political Support for Market Reforms in Latin America. Latin American Politics and Society, Miami, v. 44, n. 2, p. 1-40, Summer.

AZPIAZU, D. \& SCHORR, M. 2003. Privatizaciones. La renegociación de contratos entre la administración Duhalde. ¿Replanteo integral de la relación estado-empresas privatizadas o nuevo sometimiento a los intereses de estas últimas? Revista Realidad Económica, Buenos Aires, n. 193, ene.-feb.
BAER, W.; ELOSEGUI, P. \& GALLO, A. 2001. The Achievements and Failures of Argentina's Neo-liberal Economic Policies. Urbana : University of Illinois.

BLUSTEIN, P. And the Money Kept Rolling In (And Out). 2006. Wall Street, the IMF and the Bankrupting of Argentina. New York : Public Affairs.

BONVECCHI, A. 2004. O governo de Kirchner: uma reversão do menemismo? In : SALLUM JR., B. (org.). Brasil e Argentina hoje: política e economia. Bauru : USC, p. 187-214. 
2005. Political Processes in Argentine Economic Federalism: Fiscal Federal Negotiations, 1983-1999. In : ANNUAL MEETING OF THE LATIN AMERICAN AND CARIBBEAN ECONOMIC ASSOCIATION, 10, Paris. Paris : Lacea. Disponível em : <http:// wwwtest.aup.edu/lacea2005/system/ step2_php/papers/bonvecchi_abon.pdf $>$. Acesso em : 13.abr.2009.

BONVECCHI, A. \& GIRAUDY, A. 2007. Argentina: crecimiento económico y concentración del poder institucional. Revista de Ciencia Política, Santiago, v. 27, número especial, p. 29-42.

BOSCHI, R. \& GAITÁN, F. 2008. Gobiernos Progresistas, Agenda neodesarollista y capacidades estatales: la experiencia recente en Argentina, Brasil y Chile. Análise de Conjuntura OPSA, Rio de Janeiro, n. 1, jan. Disponível em : < http://observatorio.iuperj.br/pdfs/ 41_analises_AC_n_1_jan_2008.pdf $>$. Acesso em : 12.jan.2008.

BOSOER, F. 2006. 1999-2003: el auto-rescate de las democracias sudamericanas. Una hipótesis sobre la eficacia del "componente parlamentario". Pensamiento Proprio, Buenos Aires-Caracas, n. 23, p. 113-140, ene.-jun.

BRESSER-PEREIRA, L. C. \& NAKANO, Y. 2003. Crescimento econômico com poupança externa? Revista de Economia Política, São Paulo, v. 23, n. 2, p. 3-27, abr.jun. Disponível em : <http://www.rep.org.br/pdf/90-1.pdf>. Acesso em : 29.abr.2009.

CAVALLO, D. 2003. La Argentina y el FMI durante las dos administraciones Bush. Conferência apresentada no Centro de Estudos Latino Americanos David Rockefeller. Boston : Havard University. Disponível em : <http:// www.cavallo.com.ar/wp-content/uploads/ Argentina_y_el_FMI.pdf $>$. Acesso em : 13.abr.2009.

CHERESKY, I. 1998. Argentina. Posibilidades y obstáculos a la alternancia. Nueva Sociedad, Buenos Aires, n. 153, p. 4-14, ene.-feb.

COSTA, A.; KICILLOF, A. \& NAHÓN, C. 2004. Las consecuencias económicas del $\mathrm{Sr}$. Lavagna: dilemas de un país devaluado. Revista Realidad Económica, Buenos Aires, n. 203, p. 70-100, abr.-mayo.
DAMILL, M.; FRENKEL, R. \& RAPETTI, M. 2005. La deuda argentina: historia, default e reestructuración. Desarrollo Económico, Buenos Aires, v. 45, n. 178, p. 187-233, jul.set.

DE LUCA, M. 2007. Argentina: instituciones débiles, economía a los tumbos. Revista Relações Internacionais, Lisboa, n. 13, mar.

ESCOLAR, M.; CALVO, E.; CALCAGNO, N. \& MINVIELLE, S. 2002. Últimas imágenes antes del naufragio: las elecciones de 2001 en Argentina. Desarrollo Econômico, Buenos Aires, v. 42, n. 165, p. 25-44, abr.-jun.

FAUCHER, P. \& ARMIJO, L. E. 2004. Crises cambiais e estrutura decisória: a política de recuperação econômica na Argentina e no Brasil. Dados, Rio de Janeiro, v. 47, n. 2, p. 297334.

FERNÁNDEZ ALONSO, J. 2006. La reinserción financiera como eje rector de la agenda externa argentina post-default. In : CENTRO DE ESTUDIOS DE RELACIONES INTERNACIONALES (CERIR). La Política Exterior Argentina (2003-2005). Rosario : Universidad Nacional de Rosario.

FRENKEL, R. \& RAPETTI, M. 2006. Monetary Exchange Rates Policies in Argentina After the Convertibility Regime Collapse. Buenos Aires : Center for the Study of State and Society. Disponível em : <http://www.cepr.net/ documents / publications/argentina_2007_04.pdf>. Acesso em : 13.abr.2009.

GODIO, J. 2006. El tiempo de Kirchner: el devenir de uns "revolución desde arriba". Buenos Aires : Letra Grifa.

GOUREVITCH, P. 1986. Politics in Hard Times: Comparative Responses to International Economic Crisis. London : Cornell University.

HELLEINER, E. 2005. The Strange Story of Bush and the Argentine Debt Crisis. Third World Quarterly, Oxon (UK), v. 26, n. 6, p. 951-969. Disponível em : <http://www.forums.socioeco. org/d_read/intreg/LR_951-969.pdf >. Acesso em : 13.abr.2009.

KLAGSBRUNN, V. H. 2006. Brazil and Argentina: Two Different Approaches Taken to Development Within the Limitations Imposed by Foreign Debt. In : GARNET CONFERENCE, Amsterdam. Amsterdam : Garnet 
Network of Excellence. Disponível em : <http:/ /www.garnet-eu.org/fileadmin/documents/ w o r k s h o p _ r e p o r t s / J E R P \% $205.2 .4 \% 3$ A \% 20 G lobal\% 20Economic\%20Governance\%20and\%20Market\% 20Regulation/Klagsbrun_Garnet_2006.pdf>. Acesso em : 13.abr.2009.

KRASNER, S. D. (ed.). 1983. International Regimes. Ithaca, N. Y.: Cornell University.

MALAMUD, A. 2004. Winning Elections Versus Governing: a Two-tier Approach to Party Adaptation in Argentina, 1983-2003. In : ALCÁNTARA, M. \& ESPÍNDOLA, R. (eds.). Political Parties in Latin America. London : Routledge. Disponível em : <http://www.iue.it/ Personal/Researchers / malamud/ Party\%20adaptation\%20in\%20Argentina\%20 (A\&E\%20book).pdf $>$. Acesso em : 13.abr.2009.

MALAMUD, C. 2002. Argentina: la crisis que no cesa. Madrid : Real Instituto Elcano. Dísponível em : <http://www.realinstituto elcano.org/wps/portal/rielcano/ contenido?WCM_GLOBAL_CONTEXT=/ Elcano_es/Zonas_es/America+Latina/ARI+92002>. Acesso em : 13.abr.2009.

MENDONÇA, A. R. 2004. Mecanismos de Reestruturação da Dívida Soberana: Nova Institucionalidade ou Novas Práticas de Mercado? In : ENCONTRO ANUAL DAASSOCIAÇÃO NACIONAL DE PÓS-GRADUAÇÃO E PESQUISA EM CIÊNCIAS SOCIAIS, 28, Caxambu. Anais... Caxambu : Anpocs.

2005. Reestruturação da dívida argentina: proposta e resultados. Economia Política Internacional: análise estratégica, Campinas, $\mathrm{n}$. 4, p. 12-18, jan.-mar.

MOCCA, E. 2005. O futuro incerto dos partidos políticos argentinos. Estudos Avançados, São Paulo, v. 19, n. 55, p. 49-63, set.dez.

MORTIMORE, M. \& STANLEY, L. 2006. Obsolescencia de la protección a los inversores extrajeiros después de la crisis argentina. Revista de la CEPAL, Santiago, n. 8, p. 1734, abr.

MUSSA, M. 2002. Argentina and the Fund: From Triumph to Tragedy. Washington, D. C. : Institute for International Economics.
NOVARO, M. 2003. Presidentes, equilibrios institucionales y coaliciones de gobierno en Argentina (1989-2000). In : LANZARO, J. Tipos de Presidencialismo y Coaliciones Políticas en América Latina. Buenos Aires : Clasco, p. 51-100.

2006. Historia de la Argentina Contemporánea: de Perón a Kirchner. Buenos Aires : Edhasa.

RAPETTI, M. 2005. La macroeconomía argentina durante la post-Convertibilidad: evolución, debates y perspectivas. New York : The Argentina Observatory.

RAPOPORT, M. 2000. El Plan de Convertibilidad y la economía argentina. Economia e Sociedade, Campinas, v. 9, n. 2, p. 15-47, dez.

ROMERO, L. A. 2005. História contemporânea da Argentina. Rio de Janeiro : J. Zahar.

SCHVARZER, J. 1994. La reforma económica en la Argentina: ¿qué fuerzas sociales y para qué objetivos? Revista de Economia Política, São Paulo, v. 14, n. 4, p. 76-96, out.dez.

SOLA, L. 2008. O estado da democracia. O Estado de São Paulo, São Paulo, 29.abr.

STARR, P. 1997. Government Coalitions and the Viability of Currency Boards: Argentina Under the Cavallo Plan. Journal of Interamerican Studies and World Affairs, Miami, v. 39, n. 2, p. 83-133, Summer. Disponível em : < http:// findarticles.com/p/articles/mi_qa3688/ is_199707/ai_n8772913/>. Acesso em : 14.abr.2009.

TORRE, J. C. 2004. A crise da representação partidária na Argentina. In : SALLUM Jr., B. (org.). Brasil e Argentina hoje: política e economia. Bauru : USC, p. 153-214.

VADELL, J. A. 2006. A Política Internacional, a Conjuntura Econômica e a Argentina de Néstor Kirchner. Revista Brasileira de Política Internacional, Brasília, v. 49, n. 1, p. 194-214, jan.jun. Disponível em : <http://www.scielo.br/ scielo.php?script=sci_pdf\&pid=S003473292006000100011\&lng=en\&nrm=iso\&tlng=pt $>$. Acesso em : 14.abr.2009.

WISE, C. 2001. Currency board na Argentina: laços que unem? Revista de Economia Política, São Paulo, v. 21, n. 3, p. 168-194, jul.-set. Disponível em : <http://www.rep.org.br/pdf/ 83-9.pdf $>$. Acesso em : 14.abr.2009. 


\section{OUTRAS FONTES}

After Alvarez: Argentina’s Wobbling Alliance. 2000. The Economist, London, 12.Oct.

ARGENTINA. MINISTÉRIO DE ECONOMIA E PRODUCIÓN. 2007. Lineamentos Estratégicos para el Desarrollo Productivo de la Argentina. Buenos Aires. Disponível em: <http:/ /www.m

ARGENTINA. MINISTÉRIO DE ECONOMIAY PRODUCCIÓN. 2008a. Instituto Nacional de Estadística e Censos de la República Argentina. Disponível em : <http://www.indec.mecon. gov.ar>. Acesso em : 29.abr.2008.

ARGENTINA. MINISTÉRIO DEL INTERIOR. 2008b. Disponível em : <http:// www.mininterior.gov.ar>. Acesso em : 13.abr.2008.

Argentina's Economy: Poised for Growth? 2003. The Economist, London, 3.Apr.

BRASIL. BANCO CENTRAL DO BRASIL. 2007. Glossário. Brasília : Banco Central. Disponível em : <http://www.bcb.gov.br/ glossario.pdf $>$. Acesso em : 13.abr.2009.

Cristina's challenges. 2007. The Economist, Economist Intelligence Unit ViewsWire, London, 26.out.

De la Rua's surprise for Argentina. 2000. The Economist, London, 17.Feb.

Duhalde heads for the door. 2002. The Economist, London, 4.Jul.

The Empty-handed Social Democrat. Argentina’s
New President. 2003. The Economist, London, 29.May.

First Blows. 2003. The Economist, London, 3.Jul.

The IMF Climbs Aboard; Argentina's Economy. 2003. The Economist, London, 23.Jan.

INTERNATIONAL MONETARY FUND. 2003.

Request for Stand-by Arrangement and Request for Repurchase Expectations - Staff Report; Assessment of the Risks to the Fund and the Fund's Liquidity Position and Report on Exceptional Access for Request of Standby Arrangement - Staff Supplements; Staff Statement; Press Release on the Executive Board Discussion; and Statement by the Executive Director for Argentina. IMF Country Report n. 03/392.Washington D. C. : IMF.

Néstor Kirchner's Nimble Cookery. 2003. The Economist, London, 11.Set.

New man, old woes. 2002. The Economist, London, 2.May.

\section{ORGANIZACIÓN DE LAS NACIONES UNI-} DAS. 2007. Comisión Económica para América Latina y el Caribe. Argentina. In : Estudio Económico de América Latina y el Caribe, 2005-2006. Santiago : CEPAL.

. 2008. Comisión Económica para América Latina y el Caribe. Argentina. In : ORGANIZACIÓN DE LAS NACIONES UNIDAS. Estudio Económico de América Latina y el Caribe, 2006-2007. Santiago : CEPAL. 


\section{Roberta Rodrigues Marques da Silva}

The purpose of this article is to provide an analysis of the influence of economic crisis on the formation of new political coalitions in Argentina as they emerged in the 2000s, and how the latter have led to a break with the economic policy established by the Menem and De la Rua governments. These transformations permitted a change in the Kirchner government strategies in relation to the International Monetary Fund (IMF), leading to a harsher Argentine position that has resisted IMF positions. The economic policies sustained by the Duhalde and Kirchner administrations have taken a competitive foreign exchange model as their basis, substituting the exchange regime that was in vigor during the 1990s, and has been able to rely on entrepreneurial groups working within the domestic market favored by the peso's devaluation. These governments' proposal for promoting economic growth excluded actors with external ties linked to the coalitions that supported the Menem and De La Rua administrations. Among those excluded were the creditors who had held government securities in default since 2001 and firms who provided subcontracted public services during the 1990s and received IMF support. This explains why negotiations with the IMF during the Kirchner administration were marked by impasses and why Argentine negotiators were able to show such firmness. Transformations on the international scene also had a heavy impact on Kirchner government negotiations with the IMF. With George W. Bush's election as president of the US in the year 2000, North American support for IMF loan concession to developing countries was weakened. The Republican government defended a further reduction in the IMF role in mediating negotiations between debtor countries and private creditors. The Argentine government felt that at this point it would be able to dispense with the intermediary role of international financial institutions in negotiation of public debt.

KEYWORDS: Argentina; coalitions; neoliberalism; Néstor Kirchner; IMF. 
L'ARGENTINE ENTRE LES RÉFORMES ÉCONOMIQUES NÉOLIBERALES ET LA REDÉFINITION DES NÉGOCIATIONS AVEC LE FMI (1989-2007)

Roberta Rodrigues Marques da Silva

Cet article a pour objectif d'analyser l'influence de la crise économique sur la formation de nouvelles coalitions politique dans l'Argentine des années 2000, qui ont mené à la rupture de la politique économique adoptée par les gouvernements Menem et De la Rúa. Ces transformations ont favorisé un changement dans la stratégie du gouvernement Néstor Kirchner concernant les relations avec le Fonds Monétaire International (FMI), ce qui a engendré une position plus dure de la part du gouvernement argentin et un rejet des positions du FMI. La politique économique soutenue par les gouvernements Duhalde et Kirchner s'est appuyée sur le régime de change compétitif, à la place du régime de conversion en vigueur dans les années 1990, et comptait sur l'appui des groupes d'entrepreneurs orientés vers le marché domestique, mieux lotis en fonction de la dévalorisation du " peso ». La proposition de ces gouvernements pour la relance économique a supprimé des acteurs ayant des liens étrangers, qui participaient à des coalitions d'appui sous Menem et De la Rúa. Parmi les exclus, figuraient les créanciers ayant des papiers de la dette en moratoire depuis 2001 et les entreprises offrant des services publics qui avaient été privatisées dans les années 1990 et qui ont reçu appui du FMI. Ces raisons expliquent le fait que les négociations avec le Fonds pendant le gouvernement Kirchner ont été marquées par des impasses et par l'attitude énergique de la part des négociateurs argentins. Des transformations dans le contexte international ont également eu des impacts sur les négociations du gouvernement Kirchner avec le FMI. Avec l'élections de George W. Bush aux États-Unis, en 2000, l'appui nord-américain à la concession d'emprunts du Fonds à des pays en développement s'est affaibli. Le gouvernement républicain a encore prôné la réduction du rôle du FMI dans l'intermédiation des négocitions entre les pays endettés et les créanciers privés. Ainsi le gouvernement argentin sentait qu'il pouvait, dans ces conditions, s'affranchir de l'intermédiation des institutions financières internationales dans les négociations concernant la dette publique.

MOTS-CLÉS : Argentine ; coalitions ; néolibéralisme ; Néstor Kirchner ; FMI. 